\title{
Review
}

\section{The origin of Cretaceous black shales: a change in the surface ocean ecosystem and its triggers}

\author{
By Naohiko OHKOUCHI, ${ }^{* 1, \dagger}$ Junichiro KURODA ${ }^{* 1}$ and Asahiko TAIRA*1
}

(Communicated by Eitaro WADA, M.J.A.)

\begin{abstract}
Black shale is dark-colored, organic-rich sediment, and there have been many episodes of black shale deposition over the history of the Earth. Black shales are source rocks for petroleum and natural gas, and thus are both geologically and economically important. Here, we review our recent progress in understanding of the surface ocean ecosystem during periods of carbonaceous sediment deposition, and the factors triggering black shale deposition. The stable nitrogen isotopic composition of geoporphyrins (geological derivatives of chlorophylls) strongly suggests that $\mathrm{N}_{2}$-fixation was a major process for nourishing the photoautotrophs. A symbiotic association between diatoms and cyanobacteria may have been a major primary producer during episodes of black shale deposition. The timing of black shale formation in the Cretaceous is strongly correlated with the emplacement of large igneous provinces such as the Ontong Java Plateau, suggesting that black shale deposition was ultimately induced by massive volcanic events. However, the process that connects these events remains to be solved.
\end{abstract}

Keywords: black shale, cyanobacteria, $\mathrm{N}_{2}$-fixation, nitrogen isotope, large igneous provinces

\section{Introduction}

Black shale, the subject of this article, is a darkcolored muddy sedimentary rock that is substantially enriched in organic matter. Depending on the grade of thermal maturity, black shales are often referred to as sapropel, bituminous shale, or oil shale. This type of sediment has been deposited widely around the world and intermittently in Earth's history from the Archaean to the Holocene (Fig. 1). ${ }^{1)-4)}$ Such sediments are important from both a geological and economic point of view, because they are source rocks for petroleum and natural gas and are exploited worldwide. ${ }^{5), 6)}$ In other words, natural products derived from black shales support modern civilization and society. Furthermore, some black shales are enriched in trace metals such as vanadium, nickel, uranium, copper, and zinc, and so have often been regarded as ore deposits. ${ }^{7)}$ Although the origin of

*1 Japan Agency for Marine-Earth Science and Technology, Yokosuka, Japan.

$\dagger$ Correspondence should be addressed: N. Ohkouchi, Japan Agency for Marine-Earth Science and Technology, 2-15 Natsushima-cho, Yokosuka 237-0061, Japan (e-mail: nohkouchi@ jamstec.go.jp). black shales has been discussed for over a century, ${ }^{8)-10)}$ developments in analytical instruments and inorganic and organic geochemical techniques over the past few decades have greatly advanced research into this topic. $^{11)}$

Of the various black shales, those of the Cretaceous Period (145 to 65 million years old) have been studied most intensively. These Cretaceous black shales are characterized by episodic, contemporaneous deposition in a wide range of oceanic settings. The black shales deposited in the early Aptian around 120 million years ago, and at the Cenomanian-Turonian boundary around 94 million years ago, ${ }^{2,5), 12-14)}$ have a global distribution and an extraordinarily high organic carbon content. These intervals of black shale deposition are often referred to as Oceanic Anoxic Events (OAEs) 1a and 2, respectively. ${ }^{2,9), 15)}$ These intervals are considered to be representative of times of black shale formation during Earth history.

The stratigraphic framework of these OAEs was originally constructed from field observations of on-land geology during the early phase of OAE investigation.9),16) Since the 1970s, the Deep Sea Drilling Project (DSDP) and the subsequent scien- 

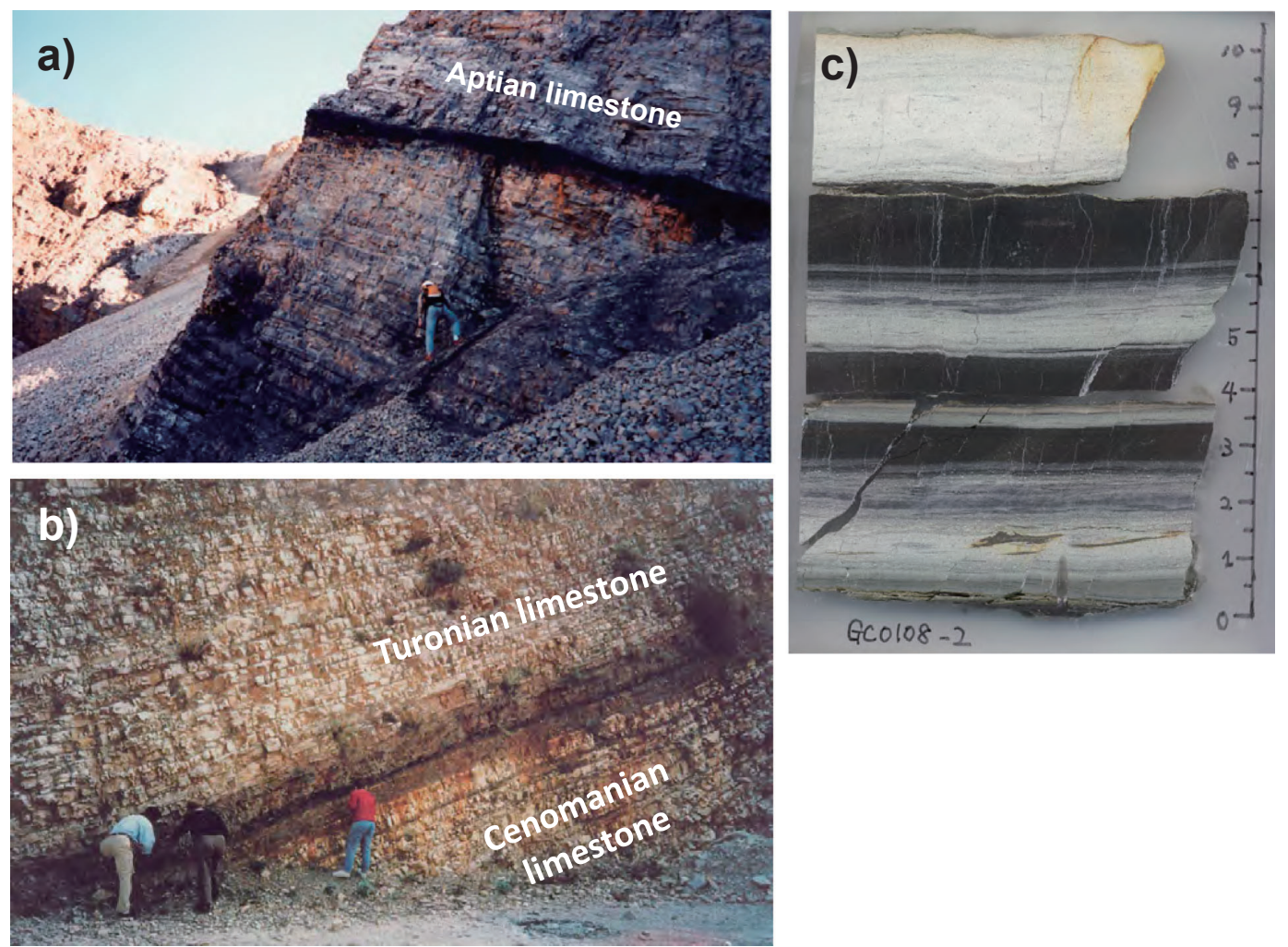

Fig. 1. Photographs of black shales. a) A black shale formed during OAE 1a (120 million years ago) cropping out at Permanente quarry, California, U.S.A. b) Livello Bonarelli black shale formed during OAE 2 (94 million years ago) exposed in the central Apennines, Italy. c) A close-up photograph of Bonarelli black shales from the Apennines. The scale bar on the right is in $\mathrm{cm}$.

tific ocean drilling programs (the Ocean Drilling Program, Integrated Ocean Drilling Program, and International Ocean Discovery Program) have played crucial roles in the study of Cretaceous OAEs by supplying relatively fresh samples of black shale from previously unsampled ocean basins. ${ }^{10)}$ Stratigraphic and micropaleontological studies have revealed the widespread occurrence of Cretaceous black shales in the Atlantic and Indian oceans, as well as on topographic highs in the Pacific Ocean. Furthermore, geochemical investigations of these black shales have provided high-quality evidence for their origin, leading to rapid progress in our knowledge of the Cretaceous OAEs over the last few decades.

Over the past two decades, the present authors have been studying the geochemistry of several black shales including the Livello Bonarelli and Livello Selli shales, which were deposited in a pelagic setting in the western Tethys during OAE 1a and OAE 2, respectively. These black shales are easily sampled, because they crop out widely in the central Apennine (Marche-Umbrian Apennines), Italy. Fortunately, they are relatively immature, ${ }^{17)}$ and thus can be used in detailed studies testing various methods to reconstruct the oceanic environment at the time of their formation. In this article, we review recent progress in our understanding of the origin of black shales, particularly of surface ocean biogeochemistry during black shale formation and the triggers for these events.

\section{Cretaceous oceanic anoxic events (OAEs)}

Full descriptions of all aspects of black shales are outside the scope of this article. Nevertheless, in this section we provide a brief overview of the geological and geochemical features of black shales, especially those formed during the Cretaceous Period, as an introduction to the topic. In Cretaceous black shales, organic carbon is noticeably (one or two orders of magnitude) concentrated relative to adjacent sediments. To our knowledge, the maximum content of organic carbon in Cretaceous black shales is more than $50 \%$, which was observed at DSDP site 367 in the Cape Verde Basin, off northwest Africa. ${ }^{18)}$ In that 


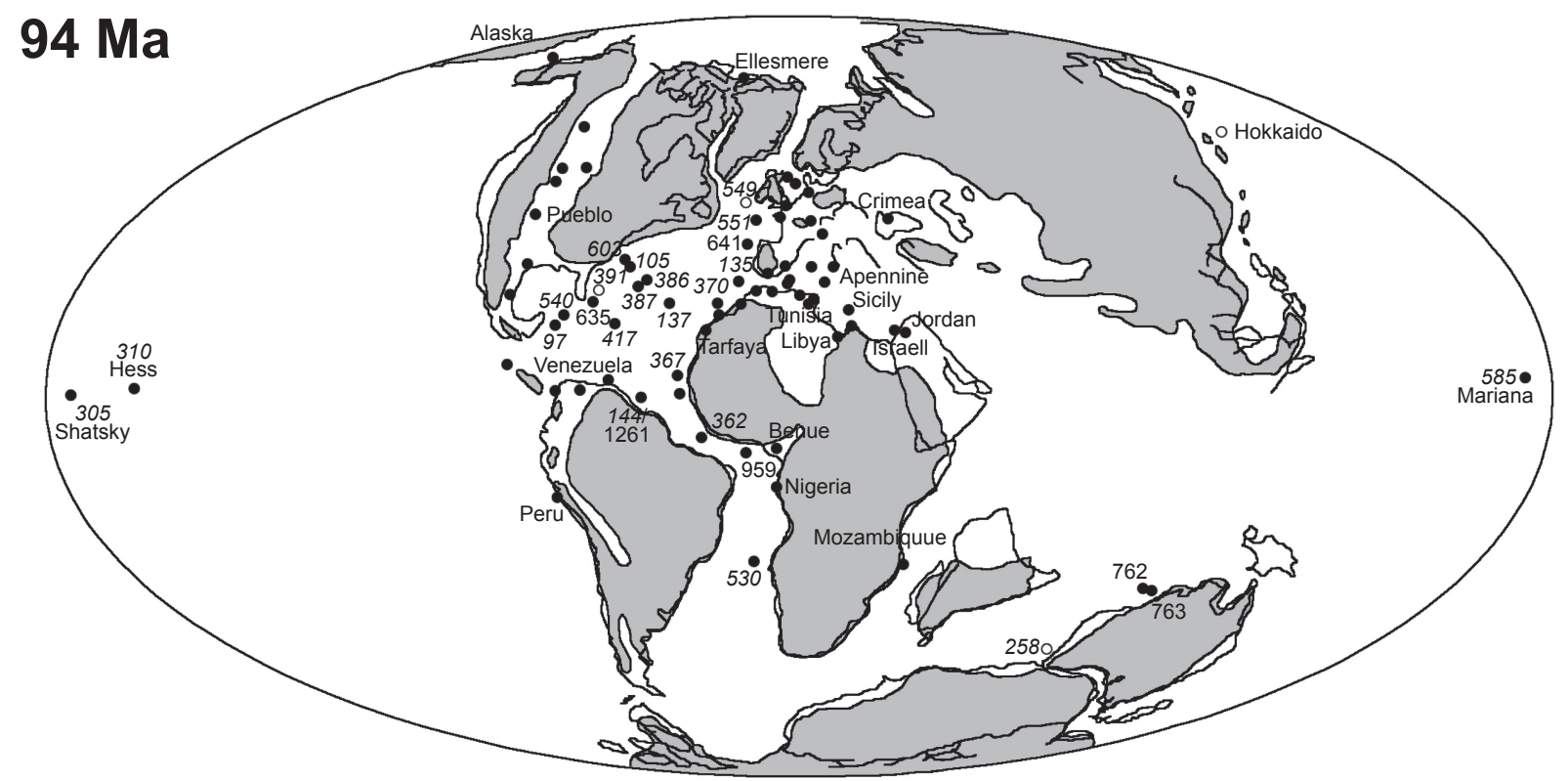

Fig. 2. World map showing the geographic distribution of black shales formed during OAE 2 (94 million years ago). Filled symbols indicate dark-colored, organic-rich sediments with organic carbon content higher than $2 \mathrm{wt} \%$; open symbols indicate organic-poor $(<2 \mathrm{wt} \%)$ sediments. The gray areas indicate the land regions at that time. Numbers indicate DSDP (in italics), ODP, and IODP drilling sites. Modified from ref. 15.

example, the organic matter probably constitutes $70 \%$ or more of the sediment. How can such organicrich sediments be formed on the pelagic seafloor? As such carbonaceous sediments have not been observed in any modern oceanic environments, obviously, in this case, the present cannot be the key to the past.

During the Cretaceous Period, black shale deposition occurred mainly during the early Aptian and around the Cenomanian-Turonian boundary. The deposition of carbonaceous sediment in these periods is also suggested by the secular variation in the stable carbon isotopic record (i.e., ${ }^{13} \mathrm{C} /{ }^{12} \mathrm{C}$ ratio) of sedimentary carbonate and organic matter, which primarily reflects the ratio of the dissolved $\mathrm{CO}_{2}$ in the surface ocean. During these two intervals of black shale deposition, carbon isotopic record shows gradual ${ }^{13} \mathrm{C}$ enrichment, which is believed to be the consequence of an elevated burial rate of ${ }^{13} \mathrm{C}$-depleted organic matter in the sediment. ${ }^{19)-24)}$ This chemical signal has also been used as a correlation tool for Cretaceous sediments. ${ }^{16), 25)-28)}$ However, detailed observations in the field and of sediment cores have suggested that at least five other Cretaceous horizons also contain carbonaceous black shales. ${ }^{12), 14), 29)-32)}$ These intervals may reflect events that were confined to certain regions. However, the geographic extent of these black shale deposition events is still unknown.
Figure 2 shows the geographical distribution of OAE 2 black shales. It should be noted that black shale deposition took place even in polar regions such as the central Arctic, although they are of Campanian-Maastrichtion age. ${ }^{33), 34)}$ In some oceanic regions, the deposition of the black shale seems not to be confined only to the time interval of OAE 2 at the $\mathrm{C}-\mathrm{T}$ boundary, but also occurred long before the typical OAE period. ${ }^{14)}$ The regions include the Demerara Rise, ${ }^{35), 36)}$ the western Venezuela coast, ${ }^{37)}$ the proximal part of the Tarfaya coastal basin in Morocco, ${ }^{38)}$ and the western interior seaway of the U.S.A. ${ }^{39)}$,40) During OAE 2, up to $25 \%$ of marine invertebrate species became extinct. ${ }^{41), 42)}$

It has been suggested that in the Cretaceous, the surface ocean temperature increased to $35^{\circ} \mathrm{C}$ in low-latitude regions, ${ }^{43)}$ and to $20^{\circ} \mathrm{C}$ or higher in polar regions. ${ }^{21), 34)}$ Based on model simulations, such high temperatures have been explained by either paleogeographic controls such as topography and continental positioning, ${ }^{44)}$ or the greenhouse effect caused by the high (up to $4500 \mathrm{ppmv}$ ) atmospheric $\mathrm{CO}_{2}$ concentration. ${ }^{45), 46)}$ Various types of geochemical evidence also suggest that the Cretaceous atmosphere was enriched in $\mathrm{CO}_{2}$ relative to the present atmosphere, although the range of reconstructed $p \mathrm{CO}_{2}$ is highly variable. $^{47)-49)}$ 
Table 1. Compilation of total organic carbon to total nitrogen weight ratio ( $\mathrm{C} / \mathrm{N}$ ratio) of Cretaceous black shales

\begin{tabular}{|c|c|c|c|c|c|}
\hline Sample & Location & Age & $\mathrm{C} / \mathrm{N}$ ratio & $\mathrm{n}$ & References \\
\hline Livello Bonarelli & North Tethys & $93 \mathrm{Ma}$ & $18-32$ & 16 & This study \\
\hline Thalmann & Central Pacific & $116 \mathrm{Ma}$ & $18-43$ & 7 & $\begin{array}{l}\text { N. Ohkouchi and W. V. } \\
\text { Sliter, unpub. data }\end{array}$ \\
\hline DSDP site 367,368 & Northeast Atlantic & $\begin{array}{l}\text { Early to Late } \\
\text { Cretaceous }\end{array}$ & $21-31$ & 10 & 63,138 \\
\hline DSDP site 530 & South Atlantic & Mid Cretaceous & $25-40$ & 9 & 60 \\
\hline DSDP site 603 & North Atlantic & Late Cretaceous & $25-72$ & 7 & 63,139 \\
\hline
\end{tabular}

It is obvious that the oceanic setting at the time of black shale formation was anoxic; hence the expression "Oceanic Anoxic Event" was introduced to denote the events in the mid-1970s. ${ }^{9)}$ Sedimentologically, the presence of fine laminae in black shale is a smoking gun of bottom-water anoxia (Fig. 1). ${ }^{50)}$ Fine laminae in black shale indicate a lack of bottomdwelling organisms, suggesting that the seafloor was covered by $\mathrm{O}_{2}$-deficient water. Geochemically, the sulfur isotopic record (i.e., the ${ }^{34} \mathrm{~S} /{ }^{32} \mathrm{~S}$ ratio) provides crucial evidence for this. Sulfur is a redox-sensitive element, and is reduced from sulfate (oxidation state: $+6)$ to sulfide $(-2)$ in an anaerobic environment. The sulfur isotopic record indicates a rapid ${ }^{34} \mathrm{~S}$-enrichment shift across the OAE 2 black shale, suggesting the existence of a large anoxic water body that led to precipitation of an appreciable amount of ${ }^{34} \mathrm{~S}$ depleted iron sulfides (mainly pyrite, FeS) from the ocean inventory. ${ }^{51)-53)}$ Simple one-box model simulations have suggested that the amount of sulfur removed from the oceanic reservoir during OAE 2 accounted for between $5 \%$ and $27 \%$ of the ocean reservoir. ${ }^{51), 53)}$

During the OAEs, the anoxic water body often expanded and invaded the lower part of the photic zone. This consideration is based on organic geochemical evidence including the presence of isorenieratane $^{54)}$ and geoporphyrins with carbon numbers greater than 34 in the black shales. ${ }^{55), 56)}$ These compounds are diagenetic derivatives of photosynthetic pigments, isorenieratene and bacteriochlorophylls $e$, respectively, from obligately anaerobic green sulfur bacteria. These green sulfur bacteria use hydrogen sulfide rather than water as an electron donor during photosynthesis, and thus inhabit strictly anaerobic environments.

There is a long-standing controversy regarding the formation mechanism of black shale. Since 1990, one of the highlighted discussions has been a dualism: productivity vs. anoxia. ${ }^{57), 58)}$ Some researchers believe that the high organic matter content in black shales can be ascribed primarily to the elevated preservation efficiency of organic matter in the ocean, which was directly caused by oxygen deficiency resulting from seawater stagnation. ${ }^{59)}$ In contrast, others have stressed the importance of elevated primary productivity in the surface ocean, which eventually causes the deep ocean to become anoxic. ${ }^{57)}$ However, this discussion focuses on only a single aspect of black shales, their elevated organic matter content, rather than explaining the various features inherent in the black shales. Below, we shed light on other features of black shales that provide some hints for solving the mystery of their formation mechanism.

\section{Bulk geochemical and morphological features of organic matter in Cretaceous black shales}

We begin the discussion with the "bulk issue". One of the conspicuous, but often overlooked characteristics of the organic matter in black shales is that these rocks are considerably enriched in carbon relative to nitrogen. The carbon to nitrogen $(\mathrm{C} / \mathrm{N})$ weight ratio of organic matter deposited on the modern pelagic seafloor is generally between 5 and 10, primarily reflecting the Redfield ratio (ca. 8). Although microbial and chemical processes in the water column and sediments significantly modify the chemical structure of sedimentary organic matter, marine geologists have empirically been aware that the $\mathrm{C} / \mathrm{N}$ ratio is a relatively conservative number even over geological timescales. Notably, most black shales have $\mathrm{C} / \mathrm{N}$ ratios greater than 20 , sometimes more than 50. These values are much higher than both the Redfield ratio and the ratios of normal pelagic sediments, even though black shales were deposited in pelagic settings in many cases (Table 1). Black shales generally exhibit a strong contrast to adjacent sediments that do not have such an elevated $\mathrm{C} / \mathrm{N}$ ratio. The anomalously high $\mathrm{C} / \mathrm{N}$ ratio in black shales has been explained by either the unusual 

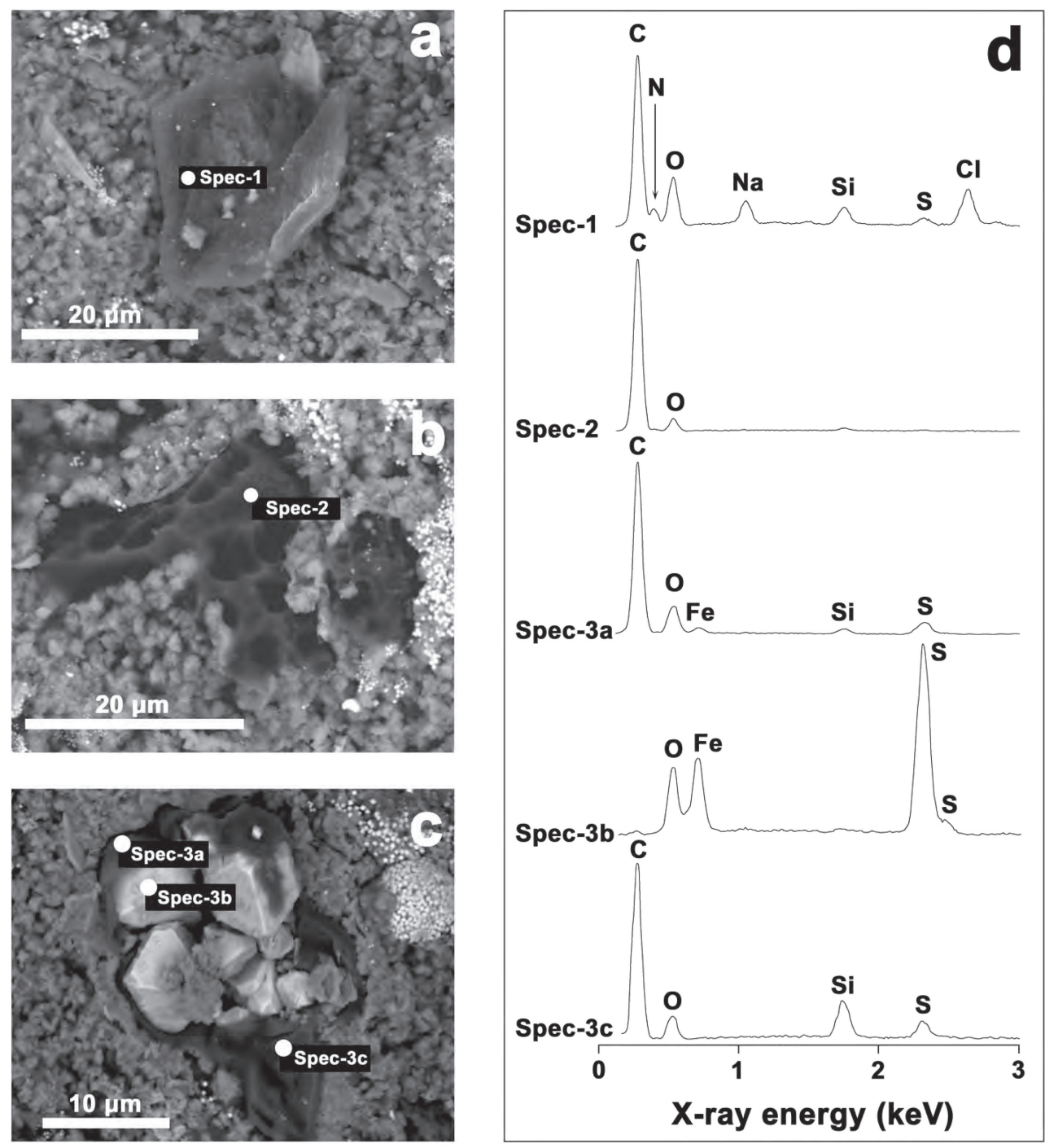

Fig. 3. Scanning electron microscopic (SEM) views of organic matter in the Bonarelli black shale (GCB19-2-7), which has a TOC content higher than $20 \%: 50)$ a) flat-shaped organic matter with a diameter of 5-20 $\mathrm{mm}$ and a thickness of less than $1 \mu \mathrm{m}$; b) fragmentary material with many spores; and c) sack-shaped material with a diameter of around $10 \mu \mathrm{m}$, which commonly contains large pyrite crystals. d) Analytical results from EDS. Note that nitrogen is significantly present only in spec-1 from the flat-shaped organic matter. Field emission SEM-EDS observations were performed with a Hitachi S-4700 equipped with Horiba EX-200 energy dispersion X-ray spectrometry. Measurements were performed under an accelerating voltage of $5-15 \mathrm{kV}$. The surface of the sample was not coated. ${ }^{61)}$

and selective removal of nitrogen relative to carbon during diagenesis, or elevated input of terrestrial organic matter. ${ }^{60)}$ However, neither explanation has been supported by convincing evidence so far.

We used scanning electron microscope coupled with energy dispersive X-ray spectroscopy (SEMEDS) to study the morphology of organic matter in black shales. ${ }^{61)}$ SEM-EDS is useful both for identifying the mineral phases making up sediment and for rough estimation of the $\mathrm{C} / \mathrm{N}$ ratio of organic particles within the sediment (Fig. 3). Based on our observations, organic matter in black shale is generally present as particles and fragments that are a few to a few tens of micrometers in diameter. These organic particles have variable shapes, but can be roughly categorized into three types: flat-shaped material 5$20 \mu \mathrm{m}$ in diameter and less than $1 \mu \mathrm{m}$ in thickness; fragmentary material with many spores; and sackshaped material with a diameter of around $10 \mu \mathrm{m}$, commonly containing large pyrite crystals. To our 
surprise, we found that an appreciable fraction of these organic particles, particularly the sack-shaped organic matter, contains little nitrogen, resulting in extremely large values of the $\mathrm{C} / \mathrm{N}$ ratio. ${ }^{61)}$ This evidence strongly suggests that the elevated $\mathrm{C} / \mathrm{N}$ ratio of bulk black shale can be explained by a significant input of nitrogen-depleted organic particles to the black shale, rather than by selective removal of nitrogen during diagenesis. Structural components of terrestrial vascular plants such as lignin and cellulose, have a fairly large $\mathrm{C} / \mathrm{N}$ ratio. However, close examination of SEM images indicated that the nitrogen-depleted sack-shaped organic particles are not typical tree fragments or pollen (Fig. 3). Sedimentological evidence suggests that the Tethyan black shales generally contain little terrigenous admixture. ${ }^{2}$ Furthermore, the Bonarelli black shale was deposited in a pelagic setting with an estimated mean sedimentation rate of as low as 1 to $3 \mathrm{~mm} \mathrm{kyr}^{-1}$, suggesting only a minor contribution of allochthonous material. ${ }^{51), 62)}$ The organic matter in the black shales was produced mainly in the ocean, and must originally have had a high $\mathrm{C} / \mathrm{N}$ ratio.

\section{Evidence from isotopic composition of geoporphyrins}

What is the high- $\mathrm{C} / \mathrm{N}$ organic matter produced in the ocean? Most bulk nitrogen isotopic records have suggested that $\mathrm{N}_{2}$-fixers (i.e., diazotrophs) are important contributors, because they are mostly confined in a typical range of $\mathrm{N}_{2}$-fixation $\left(\delta^{15} \mathrm{~N}=\right.$ $-2 \%$ to $0 \%$ o. ${ }^{17), 63), 64)}$ Here, $\delta$ denotes isotopic abundance and is defined by $\delta \equiv 10^{3}\left[R_{\text {sample }} / R_{\text {standard }}-1\right]$, where $R={ }^{15} \mathrm{~N} /{ }^{14} \mathrm{~N}$ and the standard is atmospheric $\mathrm{N}_{2}$ (AIR). The isotopic signature of sedimentary bulk nitrogen has been known to be complicated by the contribution of inorganic nitrogen ${ }^{65}$ and by post-depositional processes within the sediment. ${ }^{66)}$ To circumvent this concern, several groups have explored the isotopic composition of a series of sedimentary organic molecules called geoporphyrins in the Bonarelli and Selli black shales.

Geoporphyrins are molecules that have characteristic tetrapyrrole macrocyclic structures substituted with various alkyl chains. They are generally complexed with metal ions such as vanadium oxide (as $\mathrm{VO}^{2+}$ ), nickel (as $\mathrm{Ni}^{2+}$ ), or iron (as $\mathrm{Fe}^{2+}$ ). The basic structure of geoporphyrins, especially those with an exocyclic ring in the southern part of the molecule, is strongly suggestive of origin from chlorophylls and bacteriochlorophylls, which are major photosynthetic pigments of photoautotrophs.
Therefore, organic geochemists have long regarded geoporphyrins as excellent molecular markers for photosynthetic organisms in the surface water. ${ }^{67)-69)}$

Figure 4 shows a typical chromatogram of the Ni-chelated geoporphyrin fraction extracted from the Bonarelli and Selli black shales. ${ }^{56), 70)}$ Although the fraction is a mixture of variable geoporphyrins with carbon numbers mainly between 28 and 33, deoxophylloerythroetioporphyrin (DPEP, $\mathrm{C}_{32}$ ) is the most abundant species. DPEP is one of the most abundant geoporphyrins in various organic-rich sediments. ${ }^{68), 71)}$ The chemical structure of DPEP indicates that it can potentially be derived from various types of chlorophyll. However, in practice, it represents chlorophyll $a$, which is a widespread antenna pigment relative to other chlorophylls and is quantitatively the most predominant chloropigment produced by virtually all of the oxygenic photoautotrophs. In the modern ocean, chlorophylls $c$ are the second most important chlorophyll, and are produced by various algae including diatoms, coccolithophorids, and dinoflagellates. Chlorophylls $b$ and $d$ have a limited distribution in oceanic photoautotrophs, ${ }^{72)}$ whereas the newly discovered chlorophyll $f$ appears to be also limited to particular cyanobacteria. ${ }^{73}$ The consideration that the DPEP originates from chlorophyll $a$ is consistent with it being the most abundant geoporphyrin species in most geological samples. ${ }^{68), 69), 74)}$

The isotopic record of geoporphyrins has long been considered to be a powerful tool for reconstructing the carbon and nitrogen cycles of surface water from the geological past. ${ }^{75)-77)}$ However, application of this method to geological samples is limited due to the difficulties of isolating geoporphyrins from complex mixtures of organic matter in sediment, and of measuring isotopic compositions of trace amounts of sedimentary geoporphyrins. To overcome these issues, we developed a method for isolating and purifying geoporphyrins from the complex mixture of organic molecules in black shale using highperformance liquid chromatography, ${ }^{78)}$ and improved the sensitivity of the elemental analyzer/isotope-ratio mass spectrometer (EA/IRMS) system by optimization of the elemental analyzer hardware. ${ }^{79)} \mathrm{We}$ successfully determined the nitrogen isotopic composition of geoporphyrin samples as small as $1 \mu \mathrm{g}$ (equivalent to $c a .100 \mathrm{ngN}$ ) with a sufficiently small error. Another group developed a method of determining the nitrogen isotopic composition of bulk geoporphyrins (rather than single geoporphyrin species) after they were transformed to nitrous oxide. ${ }^{80}$ ) 


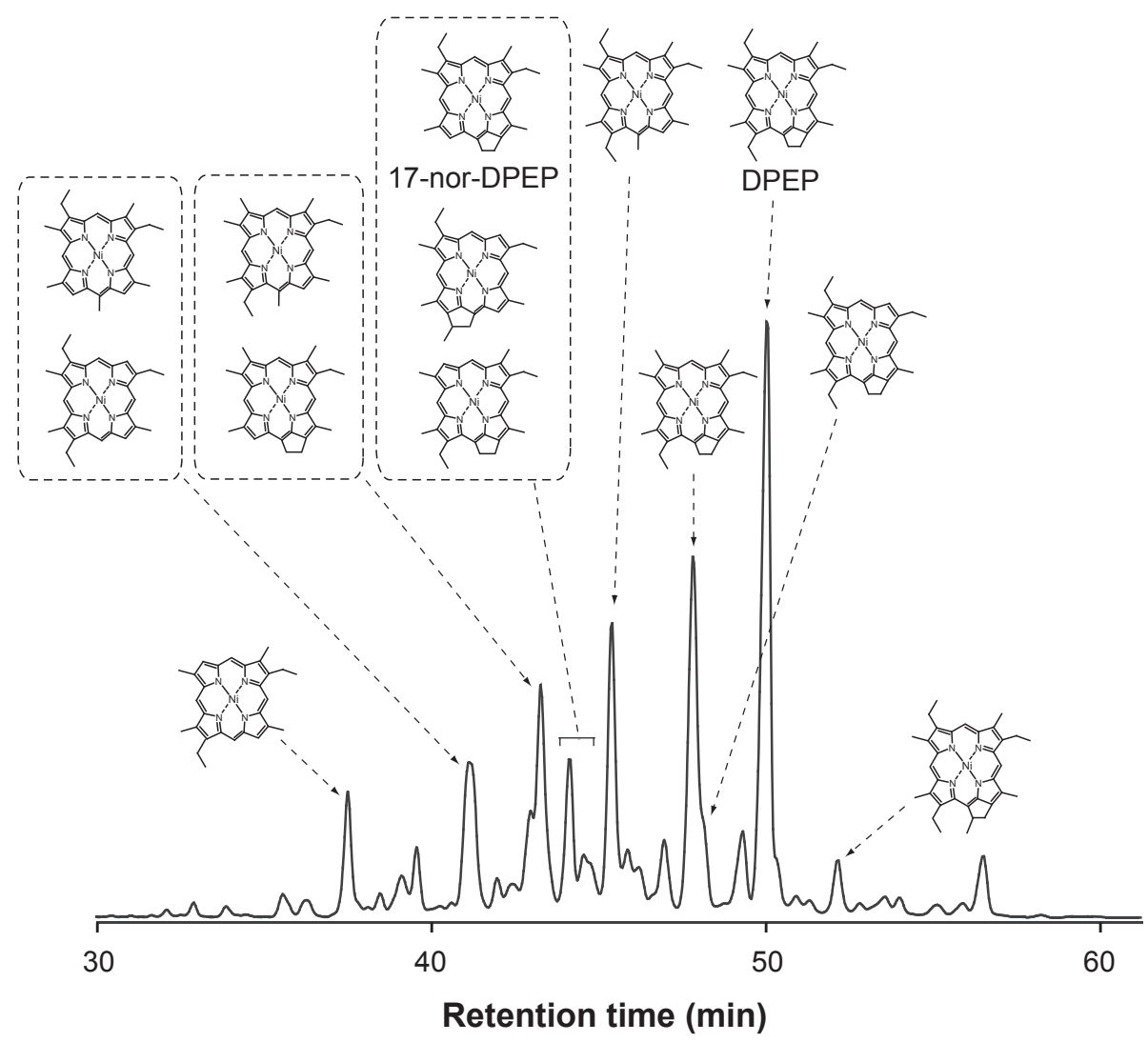

Fig. 4. Partial HPLC chromatogram (photodiode array detector; $390 \pm 5 \mathrm{~nm}$ ) of the Ni geoporphyrin fraction from a black shale sample (Livello Selli, OAE 1a). The geoporphyrin structures illustrated here were identified by nuclear magnetic resonance. ${ }^{140)}$ Two geoporphyrin species, DPEP and 17-nor-DPEP are derived mainly from chlorophyll $a$ and chlorophylls $c$, respectively. Details of the analytical procedures and instrumentation used have been described elsewhere. ${ }^{140)}$

As shown in Fig. 5, the nitrogen isotopic composition of most geoporphyrins isolated from the Bonarelli black shale is around $-5 \% .{ }^{56), 70), 81)} \mathrm{At}$ Demerara Rise, the nitrogen isotopic composition of total geoporphyrins is in the range $-7 \%$ o to $-4 \% 0^{82)}$ Investigations of modern aquatic algae have indicated that chlorophylls $a$ and $b$ are $4 \%$ to $5 \%$ depleted in ${ }^{15} \mathrm{~N}$ relative to the whole cell. ${ }^{70), 83), 84)}$ Applying this value to our results, the nitrogen isotopic composition of the phototrophic cell was estimated to be slightly more negative than $0 \%$. Such isotopic evidence suggests that the nitrogen within geoporphyrins was assimilated originally through the $\mathrm{N}_{2}$-fixation process, under the assumption that the nitrogen isotopic composition of the Cretaceous atmosphere was the same as that of today. Biological $\mathrm{N}_{2}$-fixation in aquatic plants is a process in which dissolved $\mathrm{N}_{2}$ gas is transformed to ammonium by the action of the enzyme nitrogenase. We know empirically that the isotopic fractionation associated with biological $\mathrm{N}_{2}$-fixation is very small $\left(\alpha=1.000-1.002 ; \alpha \equiv R_{\text {reactant }} / R_{\text {product }}\right) .{ }^{85)-88)}$

The carbon isotopic composition of geoporphyrins is consistent with cyanobacteria being the source of organic matter. There is a clear positive $\delta^{13} \mathrm{C}$ excursion, confirming the general trend observed in the bulk carbon isotopic record (Fig. 6). The geoporphyrins are enriched in ${ }^{13} \mathrm{C}$ by about $6 \%$ relative to the bulk organic matter, and by about $10 \%$ relative to lipid compounds such as fatty acids (derived from most organisms including bacteria) and sterols (that are never produced by cyanobacteria) from the same horizons. ${ }^{89)}$ Such ${ }^{13} \mathrm{C}$-enrichment in geoporphyrins can be explained mainly by the active transport of bicarbonate ions across the plasma membrane during carbon assimilation. ${ }^{56)}$ This $\beta$-carboxylation produces organic matter somewhat enriched in ${ }^{13} \mathrm{C}$ relative to that produced by the passive transport of $\mathrm{CO}_{2} \cdot{ }^{90)}$ The variable contribution from the $\beta$-carboxylation process potentially 


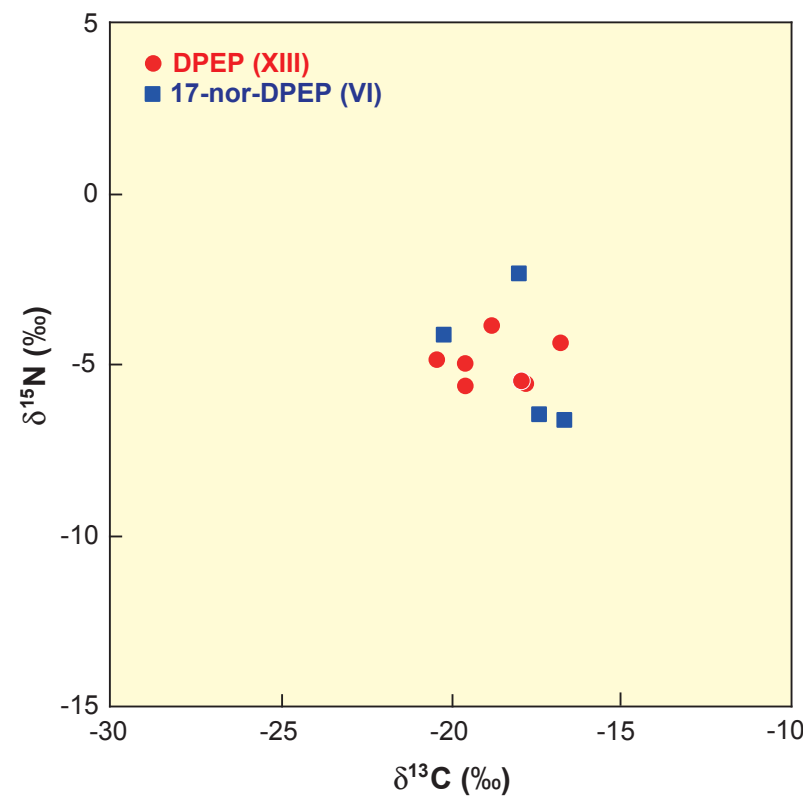

Fig. 5. Cross-plot of the carbon and nitrogen isotopic compositions of DPEP and 17-nor-DPEP isolated from OAE 1a and OAE 2 black shales collected in the central Apennines, Italy. Details of the analytical procedures and instrumentation used have been described elsewhere. ${ }^{79), 140)}$

explains a the large ( $c a .7 \%$ ), variable magnitude of the carbon isotopic difference observed in geoporphyrins between samples obtained from Italy and the U.S.A. ${ }^{91)}$

In the ocean, $\mathrm{N}_{2}$-fixation is mediated only by prokaryotic photoautotrophs including cyanobacteria and photosynthetic bacteria. As chlorophyll $a$ is the most likely source of geoporphyrins in the Bonarelli and Selli black shales, we concluded that $\mathrm{N}_{2}$-fixing cyanobacteria were major primary producers during times of black shale formation. Except for some groups, the diazotrophic (i.e., $\mathrm{N}_{2}$-fixing) cyanobacteria have specialized cells called heterocysts only where fixation of gaseous nitrogen is conducted under aerobic conditions. As free oxygen deactivates the nitrogenase, the cell wall of the heterocyst is made of a thick and densely laminated glycolipid layer with a thin polysaccharide layer on the outer surface to prevent diffusion of oxygen into the cell. ${ }^{92)}$ These glycolipids and polysaccharides lack nitrogen, and the dense structure of the cell wall is resistant to microbial attack; consequently, they could potentially be long preserved in the sediments. Our speculation is that the nitrogendepleted organic particles observed in the black shale (Fig. 3) might have been derived from the cell walls of the heterocysts of diazotrophic cyanobacteria.

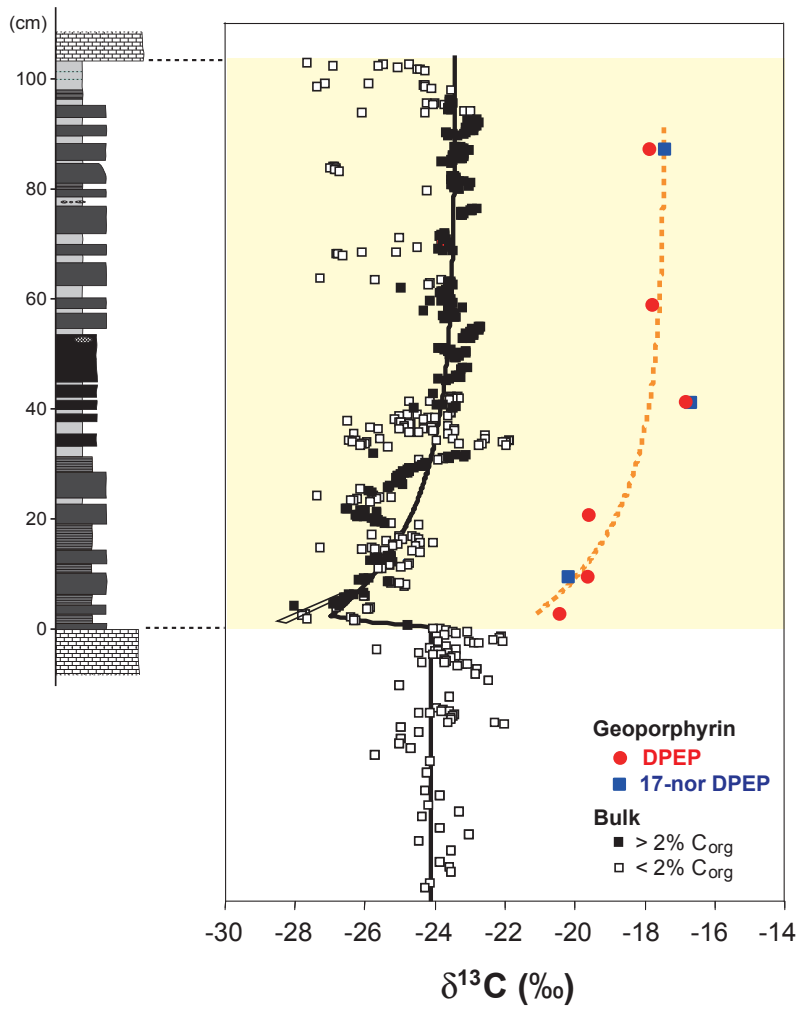

Fig. 6. Depth profiles of the carbon isotopic compositions of total bulk organic carbon and geoporphyrins (DPEP and 17-norDPEP) in the Livello Bonarelli black shale for OAE 2. The black shale layer is shaded in yellow.

Analysis of cyanobacterial slurry from a highly eutrophic lake and recent laboratory culture experiments on cyanobacteria have indicated that chlorophyll $a$ is often $\sim 10 \%$ enriched in ${ }^{15} \mathrm{~N}$ relative to the whole cell. ${ }^{93), 94)}$ Had this enrichment occurred, the $\delta$ value of whole cell of cyanobacteria should have been approximately $-15 \%$ when the black shale was formed. Higgins et al. (2012) interpreted the nitrogen isotopic record of the total geoporphyrins under this assumption, and concluded that the diazotrophs constitute only $20 \%$ of primary production. ${ }^{82}$ In our study, we measured the nitrogen isotopic compositions of not only DPEP derived from chlorophyll $a$, but also 17-nor-DPEP derived from chlorophyll $c$ produced only by algae (i.e., eukaryotes). These two porphyrins have similar isotopic compositions (Fig. 5; mean values: $\delta^{15} \mathrm{~N}_{\mathrm{DPEP}}=$ $-5.1 \%$; $\delta^{15} \mathrm{~N}_{17 \text {-nor-DPEP }}=-4.9 \%$ o). If Higgins' interpretation is correct, DPEP should be $\sim 3 \%$ enriched in ${ }^{15} \mathrm{~N}$ relative to 17 -nor-DPEP. We speculate that the cyanobacteria cultured in the nutrient-rich media has distinctively different physiology from those 
grown in the nutrient-depleted natural pelagic environment. ${ }^{95)}$ Our recent study conducted in subtropical Pacific Ocean where $\mathrm{N}_{2}$-fixers constitute a major fraction of the primary producers, chlorophyll $a$ is $\sim 1 \%$ depleted in ${ }^{15} \mathrm{~N}$ relative to POM, which is hard to be explained by $10 \%{ }^{15} \mathrm{~N}$-enrichment in chlorophyll $a$ (C. Yoshikawa, N. O. Ogawa, and N. Ohkouchi, unpublished results). Further investigation of the effect of cyanobacterial physiology on intracell ${ }^{15} \mathrm{~N}$ distribution is required to resolve this basic issue.

\section{Diatom-diazotrophic cyanobacteria association as a major photoautotroph}

Diazotrophic cyanobacteria are considered to have been major primary producers in the ocean during the Cretaceous OAEs, and thus the organic matter contained in the black shales should have originated mainly from cyanobacteria. ${ }^{17), 35), 63), 70)}$ To our knowledge, as early as 1970, Bradley suggested that cyanobacteria were the dominant source of organic matter based on extensive descriptive studies of the Green River Formation, an oil shale that was deposited in the middle Eocene. ${ }^{96)}$ The cyanobacteria are a diverse group of gram-negative prokaryotes that perform photosynthesis. Many, though not all, cyanobacteria have the ability to fix $\mathrm{N}_{2}$ under aerobic conditions. ${ }^{97)}$ Diazotrophic (i.e., $\mathrm{N}_{2}$-fixing) cyanobacteria are major primary producers in the modern tropical and subtropical ocean. The genera Trichodesmium, Synechococcus, and Richelia have frequently been observed as extensive blooms in the surface waters of the oligotrophic ocean where the seawater temperature of the surface mixed layer is generally higher than $25^{\circ} \mathrm{C} .{ }^{98)-100)}$

The ecology of these planktonic cyanobacteria remains largely unknown, and the factors controlling cyanobacterial blooms have been a matter of debate. ${ }^{101)}$ However, the availability of micronutrients such as iron is potentially a limiting factor for the formation of cyanobacterial blooms. ${ }^{102), 103)}$ Growth and reproduction of diazotrophic cyanobacteria require large amounts of the micronutrients such as iron and molybdenum because the nitrogenase contains up to 36 iron and 2 molybdenum atoms in a single enzyme to facilitate electron transfer reactions. ${ }^{104)}$ Therefore, input of these elements from the atmosphere may play a key role in controlling the production rate of diazotrophic cyanobacteria in the pelagic ocean.

Furthermore, the physical stability of the water column appears to be an essential factor for the establishment of marine cyanobacterial blooms, based on both field observations and laboratory experiments. When the upper water column is strongly stratified, nutrient renewal to surface waters through vertical mixing should be suppressed, thereby restricting the growth of various algae that are ecological competitors of cyanobacteria through limitation of nutrients such as nitrate. Moreover, planktonic cyanobacteria are known to regulate their buoyancy using gas vesicles, and without these gas vesicles they will settle out of suspension. ${ }^{105)}$ Therefore, flotation of buoyant cyanobacterial cells is favored in calm conditions, when populations of planktonic cyanobacteria may accumulate in blooms in the surface water.

Several studies have detected biomarkers that are produced abundantly by cyanobacteria in black shales. It has been known that some but not all groups of cyanobacteria synthesize 2-methyl hopanoids as membrane reinforces. ${ }^{106)}$ Several recent studies have detected derivatives of these biomarkers in black shales associated with OAE $1 \mathrm{a}$ and OAE 2 from both the North Atlantic and Pacific oceans and concluded that cyanobacteria could have been significant contributors to the black shales. ${ }^{107), 108)}$

In the Bonarelli black shales, abundant 17-norDPEP (Fig. 4), a derivative of chlorophylls $c_{1}-c_{3},{ }^{109)}$ was also observed. ${ }^{110)}$ Surprisingly, the nitrogen isotopic composition of 17-nor-DPEP is also in the range of $\mathrm{N}_{2}$-fixation (Fig. 5). Chlorophylls $c$ are produced only by algae (i.e., eukaryotes), including diatoms and dinoflagellates, but not prokaryotes such as cyanobacteria, whereas $\mathrm{N}_{2}$-fixation is an exclusively prokaryotic metabolic process. To resolve this apparent contradiction, it has been proposed that a symbiotic association of diazotrophic cyanobacteria and algae is an important primary producer. ${ }^{110)}$ This symbiosis is widespread in the modern nitrate-depleted ocean. In the present-day ocean, symbiosis between diatoms and cyanobacteria is widely observed, and the association often forms extensive blooms. For example, a bloom of the Hemiaulus-Richelia association was observed in the Amazon River plume in the western tropical Atlantic Ocean. ${ }^{111)}$ New nitrogen entering the photosynthetic system in such oceans is largely derived from cyanobacterial $\mathrm{N}_{2}$-fixation, with a lesser contribution from nitrate flux from the subsurface water. Furthermore, the diatom Rhizosolenia is known to associate with the diazotrophic cyanobacterium Richelia intracellularis. ${ }^{112)}$ In black shales formed during the latest Cretaceous that were recovered 


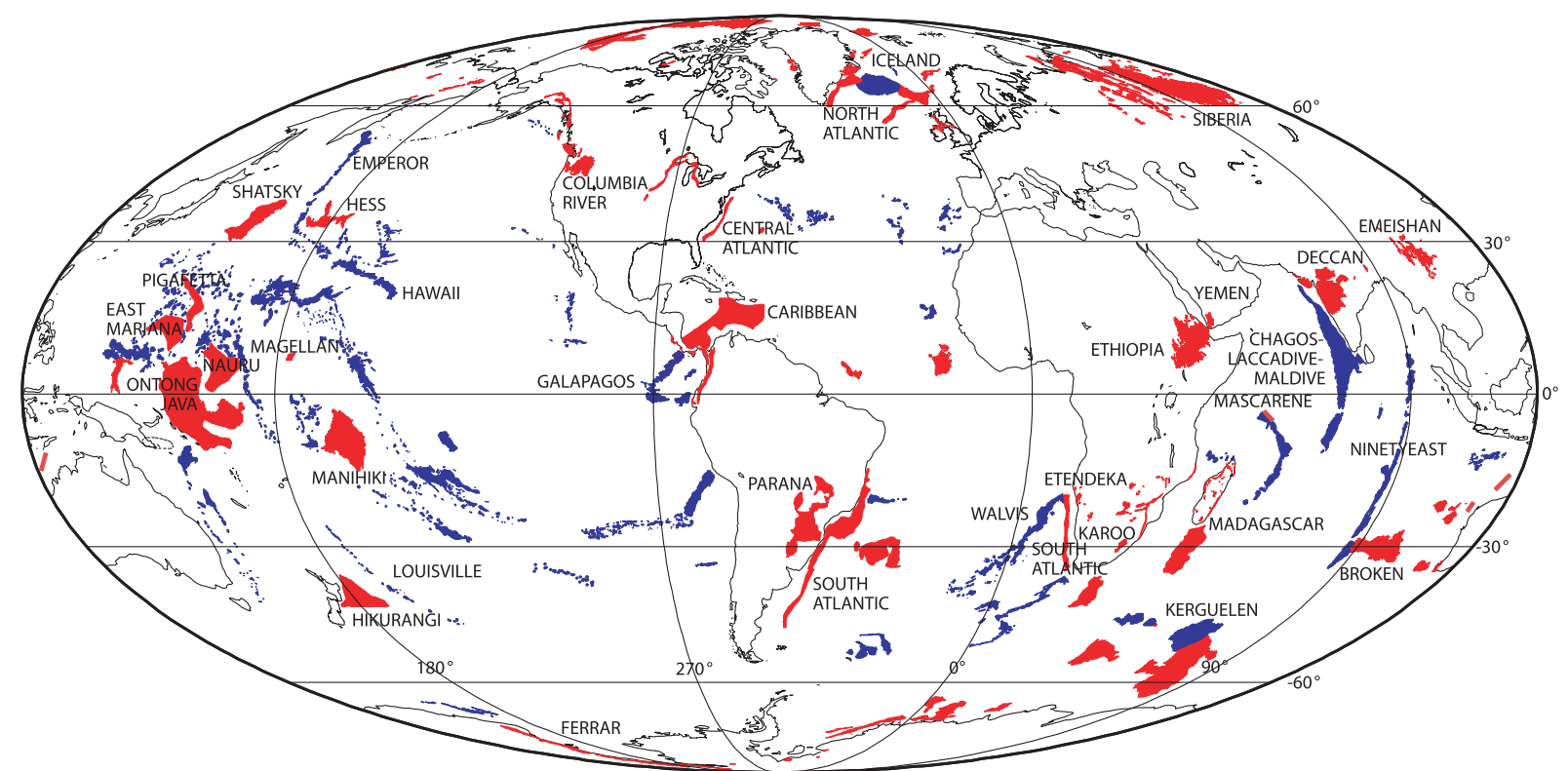

Fig. 7. Phanerozoic global LIP distribution, with transient (plume head) and persistent (plume tail) LIPs indicated in red and blue, respectively. LIPs are better preserved in the oceans where they are not subject to terrestrial erosional processes. Modified from ref. 118.

from the central Arctic, shells of the diatom genera Hemiaulus and Rhizosolenia were abundant. ${ }^{113)}$ Highly-branched isoprenoids that are produced only by Rhizosolenia ${ }^{114)}$ were also plentiful in the same sediment. ${ }^{34)}$ Furthermore, in late Quaternary Mediterranean sapropels, a recent analogue of black shales, a detailed micropaleontological study indicated that the most abundant fossil within the sapropels was Rhizosolenia. ${ }^{115)}$ These pieces of evidence indicate that the diatom-cyanobacteria endosymbiosis played an important role in oceanic primary production during black shale formation. If this was also the case for other black shales, the biogenic silica often accompanied with the black shale may be partly explained by the contribution of silicate shells from the host diatoms.

During OAEs, denitrification should have occurred around the redox boundary in the water column, reducing nitrate to $\mathrm{N}_{2}$ through $\mathrm{N}_{2} \mathrm{O}$. This process removes biologically available nitrogen from the oceanic reservoir, thus potentially decreasing the size of the oceanic biomass. However, $\mathrm{N}_{2}$-fixation may have balanced the nitrogen budget in the ocean by compensating for the nitrogen removed by denitrification. On the basis of simulations using an ocean circulation model, this homeostasis in the oceanic nitrogen cycle was operational during OAE $2^{116)}$ as well as in the modern ocean. ${ }^{117)}$ The balance between nitrate and phosphate as available nutrients could control the photoautotrophic community. Cretaceous OAEs may be representative of geological events in which the environmental system was beautifully regulated by microbial activity.

\section{The trigger for black shale formation}

A number of hypotheses have been proposed to explain the trigger for black shale deposition. Among them, the occurrence of massive volcanic eruptions associated with the emplacement of 'large igneous provinces (LIPs)' has recently been highlighted as a likely trigger for black shale deposition. LIPs are massive crustal emplacement of predominantly mafic (i.e., Fe- and Mg-rich) rock that was formed by nonplate tectonic processes, and constitute broad areas, generally larger than $10^{5} \mathrm{~km}^{2}{ }^{118)-121)}$ Formation of LIPs is thought to be a geological consequence of superplume, a giant hot-rock nucleates rising through the Earth's mantle. The voluminous mafic igneous bodies of LIPs were generally formed over short geological time intervals (less than 1 million years) with anomalously high magmatic fluxes. The locations of the LIPs are shown in Fig. 7. The midCretaceous is a period known as one of the cores of the formation of LIPs such as the Ontong Java, Manihiki, and Hikurangi plateaus (ca. 125-120 Ma), the Kerguelen Plateau (ca. 117-110 Ma), the Car- 
a) OAE-1a

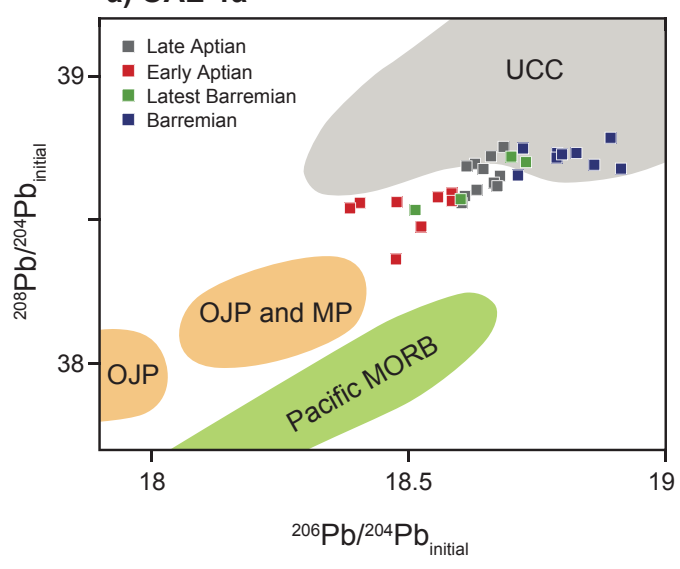

b) $\mathrm{OAE}-2$

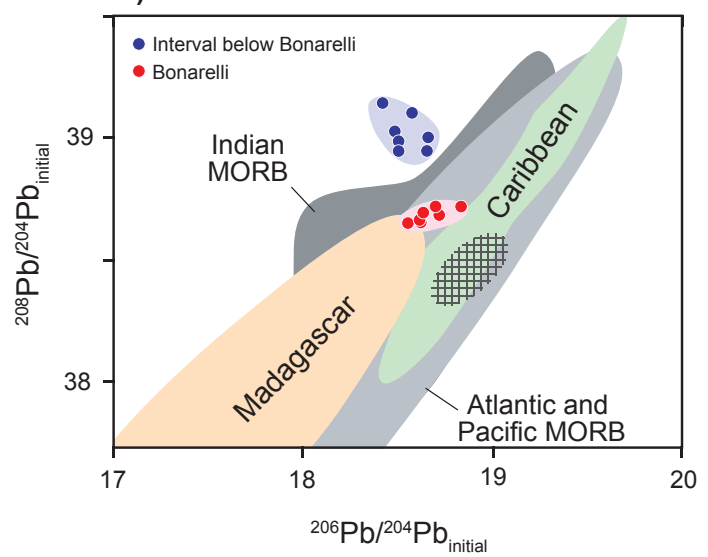

Fig. 8. Sedimentary lead isotopic records $\left({ }^{208} \mathrm{~Pb} /{ }^{204} \mathrm{~Pb}_{\text {initial }}\right.$ vs. $\left.{ }^{206} \mathrm{~Pb} /{ }^{204} \mathrm{~Pb}_{\text {initial }}\right)$ around: a) OAE $1 \mathrm{a}$, and b) OAE 2 . OAE $1 \mathrm{a}$ and $\mathrm{OAE} 2$ records were taken from the sediments collected from Shatsky Rise at ODP Site $1207 \mathrm{~B}^{131)}$ and the Livello Bonarelli black shale in the central Apennines, Italy, ${ }^{89)}$ respectively. OJP: Ontong Java Plateau, MP: Manihiki Plateau, UCC: Upper continental crust, and MORB: Mid-ocean ridge basalt.

ibbean Plateau (ca. 95-85 Ma), and the Madagascar flood basalt ( $c a .88-85 \mathrm{Ma}){ }^{118), 119)}$

Over the last few decades, a causal linkage between massive volcanism and oceanic change had been repeatedly proposed. ${ }^{122), 123)}$ However, the errors associated with the dating of both volcanic rocks and sedimentary sequences ( $c a .1$ million years) hinder the careful inspection of the temporal relationships between these events. Recent progress in our understanding of this topic has been heavily indebted to improvements in analytical instruments that enable precise measurement of the isotopic compositions of heavy metals contained in sediments in only trace amounts. The synchronicity between such massive volcanic eruptions and black shale deposition has been clearly demonstrated, especially by the analysis of the isotopic compositions of lead $\left({ }^{206} \mathrm{~Pb} /{ }^{204} \mathrm{~Pb}\right.$, ${ }^{207} \mathrm{~Pb} /{ }^{204} \mathrm{~Pb}$, and ${ }^{208} \mathrm{~Pb} /{ }^{204} \mathrm{~Pb}$ ratios) and osmium $\left({ }^{187} \mathrm{Os} /{ }^{188} \mathrm{Os}\right)$ recorded in sediments.

The stratigraphic variation of lead isotopic composition across the OAE 2 black shale of the central Apennines exhibited a large shift at the boundary between the Bonarelli black shale and the underlying limestone. ${ }^{89)}$ During black shale deposition, the isotopic composition of sedimenting lead was displaced to that of the fields of volcanic rocks from the Caribbean and Madagascar LIPs (Fig. 8). This evidence was further supported by the isotopic measurements of osmium from various sedimentary sequences across the OAE 2 black shales. The osmium isotopic composition showed a clear, negative (i.e., unradiogenic) shift during deposition of the black shale (Fig. 8). ${ }^{124), 125)}$ Furthermore, neodymium isotopic evidence confirmed LIP activity during OAE 2 (possibly Arctic rather than the Caribbean). ${ }^{126)}$ These geochemical signatures can best be explained by the deposition of mantle-derived materials supplied by the massive eruptions of either the Caribbean or the Madagascar LIP, both of which formed around OAE 2 (ca. 94 Ma). Similar synchronicity between LIP formation and black shale formation was also observed in OAE 1a, another period of global deposition of black shale. As for OAE 2 , the lead and osmium isotopic records in the OAE 1a sediments indicated obvious, rapid sedimentation of mantle-derived materials during that time (Figs. 8 and 9). ${ }^{127)-129)}$ These geochemical records were ascribed to the massive eruptions associated with the formation of the main body of the Ontong Java Plateau, the largest oceanic plateau on Earth. ${ }^{130}$ )

The details of the mechanism by which massive volcanism drove the environmental extremes remains a matter of debate. ${ }^{131)}$ One potential scenario is that global warming caused by volcanic outgassing of greenhouse gases such as $\mathrm{CO}_{2}$ enhanced continental weathering, and the subsequent increase in riverine input of nutrients (e.g., phosphorus and iron) to the ocean. This scenario may explain the collapse of the nutrient balance (i.e., enriched in phosphorus and iron, but depleted in nitrogen) in the ocean. Enhanced weathering of the continental crust or LIP basalt at the beginning of OAEs has been suggested by ${ }^{87} \mathrm{Sr} /{ }^{86} \mathrm{Sr}$ records obtained from shallow marine carbonate $^{132)}$ as well as non-traditional stable iso- 
a) OAE-1a

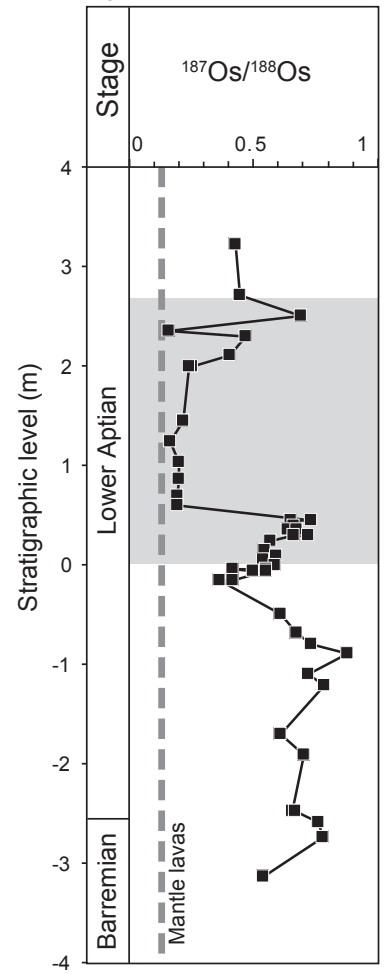

b) OAE-2

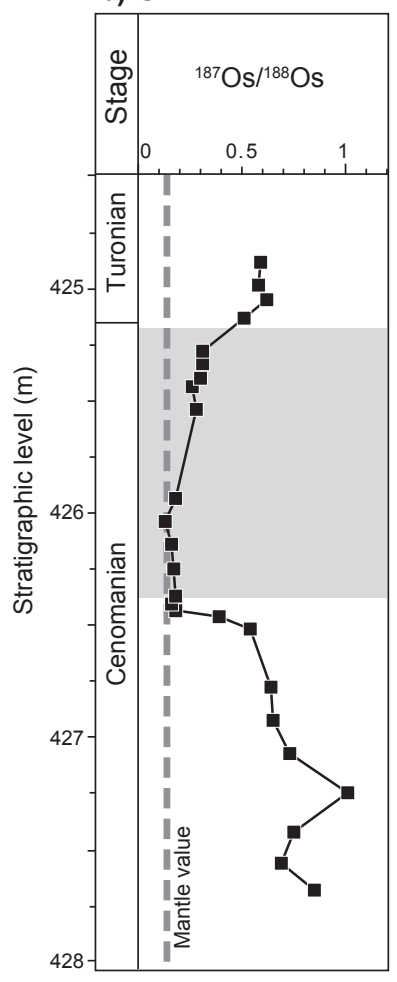

Fig. 9. Time-series sedimentary osmium isotopic records $\left({ }^{187} \mathrm{Os} /\right.$ ${ }^{188} \mathrm{Os}$ ) through: a) OAE $1 \mathrm{a}$, and b) OAE 2 sections. OAE $1 \mathrm{a}$ and OAE 2 records were taken from the sediments collected from the Livello Selli in the central Apennines, Italy $\left.{ }^{127}\right)$ and the Demerara Rise at ODP Site $1260 \mathrm{~B},{ }^{124)}$ respectively. Shaded areas indicate black shales. The Os isotopic ratio of mantle material is indicated by broken lines.

topic compositions such as the ${ }^{44} \mathrm{Ca} /{ }^{40} \mathrm{Ca}$ ratio ${ }^{133)}$ and ${ }^{7} \mathrm{Li} /{ }^{6} \mathrm{Li}$ ratio ${ }^{134)}$ of calcareous sediments. On the basis of numerical simulations, outgassing of $8 \times$ $10^{18} \mathrm{~mol} \mathrm{CO}_{2}$ is required to induce global anoxia by intensifying continental weathering and increasing the supply rate of phosphate to the ocean. ${ }^{135)}$

In addition to emissions of $\mathrm{CO}_{2}$, LIP formation is accompanied by the release of heat, hydrothermal fluid, and volcanic gases such as sulfate. These inputs could potentially have affected the dynamics and chemistry of the ocean and the atmosphere. Hydrothermal activity associated with the large-scale submarine magmatism of LIPs may have been partly responsible for the reduction of dissolved oxygen in the ocean through oxidation of reduced material in hydrothermal effluent. ${ }^{136)}$ Acidification of seawater resulting from addition of sulfate might have been responsible for the mass extinction of oceanic invertebrates.
The eruption process appears to differ between the LIPs associated with OAE $1 \mathrm{a}$ and OAE 2. Both the Caribbean and Madagascar LIPs erupted around OAE 2 were emplaced either subaerially or in shallow water, whereas the Ontong Java Plateau, which formed mainly during OAE 1a, erupted mainly in a deep submarine setting. The environmental consequences of LIP formation should be strongly dependent on the eruptive settings of LIPs. Despite many considerations, the mechanism(s) connecting LIP formation and black shale deposition are yet to be elucidated. In addition to collection of further geochemical evidence, climate simulations with a coupled atmosphere-ocean model will be necessary to diagnose the physical connection between LIP formation and oceanic change.

\section{Conclusions and implications}

Our current knowledge strongly suggests that the deposition of Cretaceous black shales was associated with changes in the surface-water ecosystem as well as deep-water anoxia. The massive volcanic events associated with LIP formation should have increased the oceanic reservoir of nutrients like iron or zinc, which potentially stimulated the oceanic primary productivity. In contrast, the stratification of the water column during OAEs should have suppressed the nutrient supply from subsurface water to photic zone, which potentially reduced the oceanic production. At this stage we do not have direct evidence indicating which effect overwhelms the other. However, blooms of $\mathrm{N}_{2}$-fixers indirectly suggested that the surface water during the OAEs were depleted in nitrate. If this were the case, climate perturbations resulting from massive volcanic events associated with LIP formation induced oligotrophy over wide areas of the ocean, with imbalance of the surface-water nitrate/phosphate ratio caused by water column denitrification. Such an oceanic state would have induced blooms of $\mathrm{N}_{2}$-fixers. Such a process is consistent with the consideration that the elevated atmospheric $\mathrm{CO}_{2}$ concentration resulting from volcanic activity could have accelerated terrestrial weathering and hence transported more phosphorus to the ocean. ${ }^{137)}$ The massive volcanic events associated with LIP formation would have eventually caused dramatic oceanic environmental change.

Fresh black shales drilled from ocean basins by future IODP explorations will be important for improving our understanding of black shales. In particular, samples from the oxic deep Pacific basin are required to know the global distribution of black 
shales, which may provide essential information regarding the formation mechanism of black shales. ${ }^{15)}$ It should also be mentioned that the black shales were formed even before the evolution of diatom during Jurassic Period. It is not clear that the symbiosis of diazotrophic cyanobacteria with other planktonic algae was also important for the formation of these black shales. Further studies are required for understanding the mystery of the black shale formation.

As described earlier, Cretaceous black shales are major source rocks of petroleum, which has been critical to our civilization since the last century. If the scenario described in this paper is correct, then the development of our civilization has been supported by solar energy collected and stored in $\mathrm{N}_{2}$-fixing cyanobacterial cells whose blooming was ultimately induced by volcanic activity. By borrowing a phrase from Jenkyns, ${ }^{2)}$ we may say that "the cyanobacteria must have colored the paths not only of geological but also of human history".

\section{Acknowledgments}

We acknowledge Dr. Eitaro Wada, M.J.A. for encouraging us to write this paper. We thank our collaborators in this long-term project, especially M. F. Coffin, H. Tokuyama, M. Tanimizu, N. O. Ogawa, Y. Takano, Y. Chikaraishi, H. Suga, Y. Kashiyama, Y. Kajiwara, M. Okada, M. Tejada, K. Suzuki, R. Hori, M. Ikehara, and T. Kanamatsu for supporting this study and fruitful discussion. We also thank two anonymous reviewers for constructive comments. This study was financially supported by JAMSTEC, MEXT, and JSPS.

\section{References}

1) Berry, W.B.N. and Wilde, P. (1978) Progressive ventilation of the oceans - An explanation for the distribution of the lower Paleozoic black shales. Am. J. Sci. 278, 257-275.

2) Jenkyns, H.C. (1980) Cretaceous anoxic events: from continents to oceans. J. Geol. Soc. London 137, 171-188.

3) Condie, K.C., Des Marais, D.J. and Abbott, D. (2000) Precambrian superplumes and supercontinents: a record in black shales, carbon isotopes, and paleoclimates? Precam. Res. 106, 239-260.

4) Trabucho-Alexandre, J., Hay, W.W. and de Boer, P.L. (2012) Phanerozoic environments of black shale deposition and the Wilson Cycle. Solid Earth 3, 29-42.

5) Arthur, M.A. and Schlanger, S.O. (1979) Cretaceous "Oceanic Anoxic Events" as causal factors in development of reef-reservoired giant oil fields.
Am. Assoc. Pet. Geol. Bull. 63, 870-885.

6) Dyni, J.R. (2006) Geology and resources of some world oil-shale deposits. U.S. Geological Survey Scientific Investigations Report 2005-5294.

7) Leventhal, J. (1993) Metals in Black Shales. In Organic Geochemistry: Principles and Applications (eds. Engel, M.H. and Macko, S.A.). Plenum, New York, pp. 581-592.

8) Twenhofel, W. (1915) Notes on black shale in the making. Am. J. Sci. 4, 272-280.

9) Schlanger, S.O. and Jenkyns, H.C. (1976) Cretaceous oceanic anoxic events - causes and consequences. Geol. Mijnb. 55, 179-184.

10) Arthur, M.A. and Sageman, B.B. (1994) Marine black shales: depositional mechanisms and environments of ancient deposits. Annu. Rev. Earth Planet. Sci. 22, 499-551.

11) Jenkyns, H.C. (2010) Geochemistry of oceanic anoxic events. Geochem. Geophys. Geosys. 11, Q03004, doi:10.1029/2009GC002788.

12) Jenkyns, H.C. (2004) Evidence for rapid climate change in the Mesozoic-Palaeogene greenhouse world. Philos. Trans. R. Soc. Lond. A 361, 18851916.

13) Gradstein, F.M., Ogg, J.G., Smith, A.G., Bleeker, W. and Lourens, L.J. (2004) A new geologic time scale, with special reference to Precambrian and Neogene. Episodes 27, 83-100.

14) Kuroda, J. and Ohkouchi, N. (2006) Implications of spatiotemporal distribution of black shales deposited during the Cretaceous Oceanic Anoxic Event2. Paleontol. Res. 10, 345-358.

15) Arthur, M.A., Brumsack, H.-J., Jenkyns, H.C. and Schlanger, S.O. (1990) Stratigraphy, geochemistry, and paleoceanography of organic carbon-rich Cretaceous sequences. In Cretaceous Resources, Events and Rhythms (eds. Ginsburg, R.N. and Beaudoin, B.). Kluwer Academic Publishers, Dordrecht, pp. 75-119.

16) Schlanger, S.O., Arthur, M.A., Jenkyns, H.C. and Scholle, P.A. (1987) The Cenomanian-Turonian Oceanic Anoxic Event, I. Stratigraphy and distribution of organic carbon-rich beds and the marine $\delta^{13} \mathrm{C}$ excursion. In Marine Petroleum Source Rocks (eds. Brooks, J. and Fleet, A.J.). Geological Society Special Publication No. 26, pp. 371-399.

17) Ohkouchi, N., Kawamura, K., Wada, E. and Taira, A. (1997) High abundances of hopanols and hopanoic acids in Cretaceous black shales. Anc. Biomol. 1, 183-192.

18) Dean, W.E., Arthur, M.A. and Claypool, G.E. (1986) Depletion of ${ }^{13} \mathrm{C}$ in Cretaceous marine organic matter: source, diagenetic, or environmental signal? Mar. Geol. 70, 119-157.

19) Scholle, P.A. and Arthur, M.A. (1980) Carbon isotope fluctuations in Cretaceous pelagic limestones: potential stratigraphic and petroleum exploration tool. Am. Assoc. Pet. Geol. Bull. 64, 67-87.

20) Jenkyns, H.C., Gale, A.S. and Corfield, R.M. (1994) Carbon- and oxygen-isotope stratigraphy of the 
English chalk and Italian Scaglia and its palaeoclimatic significance. Geol. Mag. 131, 1-34.

21) Huber, B.T., Hodell, D.A. and Hamilton, C.P. (1995) Middle-Late Cretaceous climate of the southern high latitudes: Stable isotopic evidence for minimal equator-to-pole thermal gradients. Geol. Soc. Am. Bull. 107, 1164-1191.

22) Menegatti, A.P., Weissert, H., Brown, R.S., Tyson, R.V., Farrimond, P., Strasser, A. and Caron, M. (1998) High-resolution $\delta^{13} \mathrm{C}$ stratigraphy through the early Aptian "Livello Selli" of the Alpine Tethys. Paleoceanogr. 13, 530-545.

23) Kump, L.R. and Arthur, M.A. (1999) Interpreting carbon-isotope excursions: carbonates and organic matter. Chem. Geol. 161, 181-198.

24) Bowman, A.R. and Bralower, T.J. (2005) Paleoceanographic significance of high-resolution carbon isotope records across the CenomanianTuronian boundary in the Western Interior and New Jersey coastal plain, USA. Mar. Geol. 217, 305-321.

25) Hasegawa, T. (1993) Correlation of the Cenomanian/Turonian boundary between Japan and the Western Interior of the United States. J. Geol. Soc. Jpn. 101, 2-12.

26) Tsikos, H., Jenkyns, H.C., Walsworth-Bell, B., Petrizzo, M.R., Forster, A., Kolonic, S., Erba, E., Premoli Silva, I., Baas, M., Wagner, T. and Sinninghe Damsté, J.S. (2004) Carbon-isotope stratigraphy recorded by the CenomanianTuronian Oceanic Anoxic Event: correlation and implications based on three key localities. J. Geol. Soc. London 161, 711-719.

27) Nemoto, T. and Hasegawa, T. (2011) submillennial resolution carbon isotope stratigraphy across the Oceanic Anoxic Event 2 horizon in the Tappu section, Hokkaido, Japan. Palaeogeogr. Palaeoclimatol. Palaeoecol. 309, 271-280.

28) Kuroda, J., Ihoriya, N., Hori, R.S., Ogawa, N.O., Ikehara, M., Tanimizu, M. and Ohkouchi, N. (2014) Geochemistry of Aptian bedded chert succession from the deep Pacific basin: new insights into Cretaceous Oceanic Anoxic Event1a. Geol. Soc. Am. Spec. Pub. (in press).

29) Erba, E., Bartolini, A. and Larson, R.L. (2004) Valanginian Weissert oceanic anoxic event. Geology 32, 149-152.

30) de Graciansky, P.C., Deroo, G., Herbin, J.P., Montadert, L., Müller, C., Schaaf, A. and Sigal, J. (1984) Ocean-wide stagnation episode in the late Cretaceous. Nature 308, 346-349.

31) Erbacher, J., Huber, B.T., Norris, R.D. and Markey, M. (2001) Increased thermohaline stratification as a possible cause for an ocean anoxic event in the Cretaceous period. Nature 409, 325-327.

32) Takashima, R., Nishi, H., Yamanaka, T., Tomosugi, T., Fernando, A.G., Tanabe, K., Moriya, K., Kawabe, F. and Hayashi, K. (2011) Prevailing oxic environments in the Pacific Ocean during the mid-Cretaceous Oceanic Anoxic Event 2. Nat. Commun. 2, 234.

33) Clark, D.L. (1986) Early history of the Arctic
Ocean. Paleoceanogr. 3, 539-550.

34) Jenkyns, H.C., Forster, A., Schouten, S. and Sinninghe Damsté, J.S. (2004) High temperatures in the Late Cretaceous Arctic Ocean. Nature 432, 888-892.

35) Kuypers, M.M.M., Blokker, P., Hopmans, E.C., Kinkel, H., Pancost, R.D., Schoten, S. and Sinninghe Damsté, J.S. (2002) Archaeal remains dominate marine organic matter from the early Albian oceanic anoxic event 1b. Palaeogeogr. Palaeoclimatol. Palaeoecol. 185, 211-234.

36) Erbacher, J., Friedrich, O., Wilson, P.A., Birch, H. and Mitterlose, J. (2004) Stable organic carbon isotope stratigraphy across Oceanic Anoxic Event 2 of Demerara Rise, western tropical Atlantic. Geochem. Geophys. Geosyst. 6, Q06010, doi:10.1029/2004GC000850.

37) Perez-Infante, J., Farrimond, P. and Furrer, M. (1996) Global and local controls influencing the deposition of the La Luna Formation (Cenomanian-Turonian), western Venezuela. Chem. Geol. 130, 271-288.

38) Lüning, S., Kolonic, S., Belhadj, E.M., Belhadj, Z., Cota, L., Barić, G. and Wagner, T. (2004) Integrated depositional model for the CenomanianTuronian organic-rich strata in North Africa. Earth Sci. Rev. 64, 51-117.

39) Pratt, L.M. and Threlkeld, C.N. (1984) Stratigraphic significance of ${ }^{13} \mathrm{C} /{ }^{12} \mathrm{C}$ ratios in midCretaceous strata of the Western Interior Basin. In Mesozoic of Middle North America (eds. Scott, D.F. and Glass, D.J.). Canadian Society of Petroleum Geologists Memoir 9, pp. 305-312.

40) Eldrett, J.S., Minisini, D. and Bergman, S.C. (2014) Decoupling of the carbon cycle during Ocean Anoxic Event 2. Geology 42, 567-570.

41) Kaiho, K. (1994) Planktonic and benthic foraminiferal extinction events during the last 100 m.y. Palaeogeogr. Palaeoclimatol. Palaeoecol. 111, 4571.

42) Kauffman, E.G. (1995) Global change leading to biodiversity crisis in a greenhouse world: The Cenomanian-Turonian (Cretaceous) mass extinction. In Effects of Past Global Change on Life (eds. Stanley, S.M., Knoll, A.H. and Kennett, J.). National Academy Press, Washington, D.C., pp. $47-71$.

43) Wilson, P.A. and Norris, R.D. (2001) Warm tropical ocean surface and global anoxia during the midCretaceous period. Nature 412, 425-429.

44) Barron, J. (1983) A warm equable Cretaceous: The nature of the problem. Earth Sci. Rev. 18, 305338.

45) Tajika, E. (1999) Carbon cycle and climate change during the Cretaceous inferred from a biogeochemical carbon cycle model. Island Arc 8, 293303.

46) Bice, K.L. and Norris, R.D. (2002) Possible atmospheric $\mathrm{CO}_{2}$ extremes of the Middle Cretaceous (late Albian-Turonian). Paleoceanography 17, doi:10.1029/2002PA000778.

47) Freeman, K.H. and Hayes, J.M. (1992) Fractiona- 
tion of carbon isotopes by phytoplankton and estimates of ancient $\mathrm{CO}_{2}$ levels. Global Biogeochem. Cycles 6, 185-198.

48) Ekart, D.D., Cerling, T.E., Montanez, I.P. and Tablor, N.J. (1999) A 400 million year carbon isotope record of pedogenic carbonate: Implications for paleoatmospheric carbon dioxide. Am. J. Sci. 299, 805-827.

49) Li, X., Jenkyns, H.C., Zhang, C., Wang, Y., Liu, L. and Cao, K. (2014) Carbon-isotope signatures of pedogenic carbonates from SE China: Rapid atmospheric $\mathrm{pCO}_{2}$ changes in the mid-late Early Cretaceous. Geol. Mag. 151, 830-849.

50) Kuroda, J., Ohkouchi, N., Ishii, T., Tokuyama, H. and Taira, A. (2005) Lamina-scale analysis of sedimentary components in Cretaceous black shales by chemical compositional mapping: Implications for paleoenvironmental changes during the Oceanic Anoxic Events. Geochim. Cosmochim. Acta 69, 1479-1494.

51) Ohkouchi, N., Kawamura, K., Kajiwara, Y., Wada, E., Okada, M., Kanamatsu, T. and Taira, A. (1999) Sulfur isotope records around Livello Bonarelli (northern Apennines, Italy) black shale at the Cenomanian-Turonian boundary. Geology 27, 535-538.

52) Adams, D.D., Hurtgen, M.T. and Sageman, B.B. (2010) Volcanic triggering of a biogeochemical cascade during Oceanic Anoxic Event 2. Nat. Geosci. 3, 201-204.

53) Owens, J.D., Gill, B.C., Jenkyns, H.C., Baes, S.M., Severmann, S., Kuypers, M.M.M., Woodfine, R.G. and Lyons, T.W. (2013) Sulfur isotopes track the global extent and dynamics of euxinia during Cretaceous Oceanic Anoxic Event 2. Proc. Natl. Acad. Sci. U.S.A. 110, 18407-18412.

54) Sinninghe Damsté, J.S. and Köster, J. (1998) A euxinic southern North Atlantic Ocean during the Cenomanian/Turonian oceanic anoxic event. Earth Planet. Sci. Lett. 158, 165-173.

55) Pancost, R.D., Crawford, N., Magness, S., Turner, A., Jenkyns, H.C. and Maxwell, J.R. (2004) Further evidence for the development of photiczone euxinic conditions during Mesozoic oceanic anoxic events. J. Geol. Soc. London 161, 353-364.

56) Kashiyama, Y., Ogawa, N.O., Kuroda, J., Shiro, M., Nomoto, S., Tada, R., Kitazato, H. and Ohkouchi, N. (2008) Diazotrophic cyanobacteria as the major photoautotrophs during mid-Cretaceous Oceanic Anoxic Events: nitrogen and carbon isotopic evidence from sedimentary porphyrin. Org. Geochem. 39, 532-549.

57) Pedersen, T.F. and Calvert, S.E. (1990) Anoxia vs. productivity: what controls the formation of organic-carbon-rich sediments and sedimentary rocks? Am. Assoc. Pet. Geol. Bull. 74, 454-466.

58) Demaison, G.J. (1991) Anoxia vs. productivity: what controls the formation of organic-carbonrich sediments and sedimentary rocks? Discussion. Am. Ass. Petrol. Geol. Bull. 75, 499.

59) Emerson, S. and Hedges, J.I. (1988) Processes controlling the organic carbon content of open ocean sediments. Paleoceanography 3, 621-634.

60) Meyers, P.A., Leenheer, M.J., Kawka, O.E. and Trull, T.W. (1984) Enhanced preservation of marine-derived organic matter in Cenomanian black shales from the southern Angola Basin. Nature 312, 356-359.

61) Ohkouchi, N., Kuroda, J., Okada, M. and Tokuyama, H. (2003) Why Cretaceous black shales have high $\mathrm{C} / \mathrm{N}$ ratios? Implications from SEM-EDX observations for Livello Bonarelli black shales at the Cenomanian-Turonian boundary. Front. Res. Earth Evol. 1, 239-241.

62) Arthur, M.A. and Premoli-Silva, I. (1982) Development of widespread organic carbon-rich strata in the Mediterranean Tethys. In Nature and Origin of Cretaceous Carbon-Rich Facies (eds. Schlanger, S.O. and Cita, M.B.). Academic Press, London, pp. 7-54.

63) Rau, G.H., Arthur, M.A. and Dean, W.E. (1987) ${ }^{15} \mathrm{~N} /{ }^{14} \mathrm{~N}$ variations in Cretaceous Atlantic sedimentary sequences: implication for past changes in marine nitrogen biogeochemistry. Earth Planet. Sci. Lett. 82, 269-279.

64) Junium, C.K. and Arthur, M.A. (2007) Nitrogen cycling during the Cretaceous, CenomanianTuronian Oceanic Anoxic Event II. Geochem. Geophys. Geosyst. 8, Q03002, doi:10.1029/ 2006GC001328.

65) Schubert, C.J. and Calvert, S.E. (2001) Nitrogen and carbon isotopic composition of marine and terrestrial organic matter in Arctic Ocean sediments: implications for nutrient utilization and organic matter composition. Deep Sea Res. Part I Oceanogr. Res. Pap. 48, 789-810.

66) Freudenthal, T., Wagner, T., Wezhöfer, F., Zabel, M. and Wefer, G. (2001) Early diagenesis of organic matter from sediments of the eastern subtropical Atlantic: Evidence from stable nitrogen and carbon isotopes. Geochim. Cosmochim. Acta 65, 1795-1808.

67) Treibs, A. (1936) Chlorophyll- und Häminderivate in organischen Mineralstoffen. Angew. Chem. 49, 682-686.

68) Baker, E.W. and Louda, J.W. (1986) Porphyrins in the geological record. In Biological Markers in Sediments (ed. Johns, R.B.). Elsevier, Amsterdam. pp. 125-225.

69) Callot, H.J. and Ocampo, R. (2000) Geochemistry of Porphyrins. In The Porphyrin Handbook Vol. 1 (eds. Kadish, K.M., Smith, K.M. and Guilard, R.). Academic Press, San Diego, pp. 349-398.

70) Ohkouchi, N., Kashiyama, Y., Kuroda, J., Ogawa, N.O. and Kitazato, H. (2006) The importance of diazotrophic cyanobacteria as primary producers during Cretaceous Oceanic Anoxic Event 2. Biogeosci. 3, 467-478.

71) Baker, E.W., Corwin, A.H., Klesper, E. and We, P.E. (1968) Deoxophylloerythroetioporphyrin. J. Org. Chem. 33, 3144-3148.

72) Blankenship, R.E. (2004) Molecular Mechanics of Photosynthesis. Blackwell Science, Oxford.

73) Chen, M., Schliep, M., Willows, R.D., Cai, Z.-L., 
Neilan, B.A. and Scheer, H. (2010) A red-shifted chlorophyll. Science 329, 1318-1319.

74) Keely, B.J., Harris, P.G., Popp, B.N., Hayes, J.M., Meischner, D. and Maxwell, J.R. (1994) Porphyrin and chlorin distributions in a Late Pliocene lacustrine sediment. Geochim. Cosmochim. Acta 58, 3691-3701.

75) Park, R. and Dunning, H.N. (1961) Stable carbon isotope studies of crude oils and their porphyrin aggregates. Geochim. Cosmochim. Acta 22, 99105.

76) Hayes, J.M., Takigiku, R., Ocampo, R., Callot, H.J. and Albrecht, P. (1987) Isotopic compositions and probable origins of organic molecules in the Eocene Messel shale. Nature 329, 48-51.

77) Chicarelli, M.I., Hayes, J.M., Popp, B.N., Eckardt, C.B. and Maxwell, J.R. (1993) Carbon and nitrogen isotopic compositions of alkyl porphyrins from the Triassic Serpiano oil shale. Geochim. Cosmochim. Acta 57, 1307-1311.

78) Kashiyama, Y., Kitazato, H. and Ohkouchi, N. (2007) An improved method for isolation and purification of sedimentary porphyrins by highperformance liquid chromatography for compound-specific isotopic analysis. J. Chromatogr. A 1138, 73-83.

79) Ogawa, N.O., Nagata, T., Kitazato, H. and Ohkouchi, N. (2010) Ultra-sensitive elemental analyzer/isotope ratio mass spectrometer for stable nitrogen and carbon isotopic analyses. In Earth, Life, and Isotopes (eds. Ohkouchi, N., Tayasu, I. and Koba, K.). Kyoto University Press, Kyoto, pp. 339-353.

80) Higgins, M.B., Robinson, R.S., Casciotti, K.L., Mcllvin, M.R. and Pearson, A. (2009) A method for determining the nitrogen isotopic composition of Porphyrins. Anal. Chem. 81, 184-192.

81) Kashiyama, Y., Ogawa, N.O., Kitazato, H. and Ohkouchi, N. (2010) Nitrogen and carbon isotopic compositions of copper, nickel, and vanadyl porphyrins in Cretaceous OAE black shales. In Earth, Life, and Isotopes (eds. Ohkouchi, N., Tayasu, I. and Koba, K.). Kyoto University Press, Kyoto, pp. 313-335.

82) Higgins, M.B., Robinson, R.S., Husson, J.M., Carter, S.J. and Pearson, A. (2012) Dominant eukaryotic export production during ocean anoxic events reflects the importance of recycled $\mathrm{NH}_{4}{ }^{+}$. Proc. Natl. Acad. Sci. U.S.A. 109, 2269-2274.

83) Sachs, J.P., Repeta, D.J. and Goericke, R. (1999) Nitrogen and carbon isotopic ratios of chlorophyll from marine phytoplankton. Geochim. Cosmochim. Acta 65, 1431-1441.

84) Chikaraishi, Y., Matsumoto, K., Ogawa, N.O., Suga, H., Kitazato, H. and Ohkouchi, N. (2005) Hydrogen, carbon and nitrogen isotopic fractionations during chlorophyll biosynthesis in C3 higher plants. Phytochemistry 66, 911-920.

85) Hoering, T.C. and Ford, H.T. (1960) The isotope effect in the fixation of nitrogen by Azotobacter. J. Am. Chem. Soc. 82, 376-378.

86) Wada, E. (1980) Nitrogen isotope fractionation and its significance in biogeochemical processes occurring in marine environments. In Isotope Marine Chemistry (eds. Goldberg, E.D., Horibe, Y. and Saruhashi, K.). Uchida Rokkakudo, Tokyo, pp. $375-398$.

87) Minagawa, M. and Wada, E. (1986) Nitrogen isotope ratios of red tide organisms in the East China Sea: a characterization of biological nitrogen fixation. Mar. Chem. 19, 245-259.

88) Ohkouchi, N. and Takano, Y. (2014) Organic nitrogen: Sources, fates, and chemistry. In Treatise on Geochemistry vol. 2 (eds. Freeman, K.H. and Falkowski, P.). Elsevier, Amsterdam, pp. 251-289.

89) Kuroda, J., Ogawa, N.O., Tanimizu, M., Coffin, M.F., Tokuyama, H., Kitazato, H. and Ohkouchi, N. (2007) Contemporaneous massive subaerial volcanism and late Cretaceous Oceanic Anoxic Event 2. Earth Planet. Sci. Lett. 256, 211-223.

90) Raven, J.A. (1997) Inorganic carbon acquisition by marine autotrophs. Adv. Bot. Res. 27, 85-209.

91) Hayes, J.M., Popp, B.N., Takigiku, R. and Johnson, M.W. (1989) An isotopic study of biogeochemical relationships between carbonates and organic carbon in the Greenhorn Formation. Geochim. Cosmochim. Acta 53, 2961-2972.

92) Adams, D.G. (1997) Cyanobacteria. In Bacteria as Multicellular Organisms (eds. Shapiro, J.A. and Dworkin, M.). Oxford Univ. Press, Oxford, pp. 109-148.

93) Katase, T. and Wada, E. (1990) Isolation of chlorophyll $a$ in Microcystis spp. for determination of stable isotopes of carbon and nitrogen, and variation in Suwa Lake. Bunseki Kagaku 39, 451456 (in Japanese with English abstract).

94) Tsao, L.E., Robinson, R.S., Higgins, M.B. and And Pearson, A. (2012) Nitrogen isotope ratio of cyanobacterial chlorophyll: Chemostat vs. Batsch culture. Org. Geochem. 49, 96-99.

95) Rueter, J.G. (1988) The effect of iron nutrition on photosynthesis and nitrogen fixation in cultures of Trichodesmium (Cyanophyceae). J. Phycol. 26, 30-35.

96) Bradley, W.H. (1970) Green River oil shaleConcept of origin extended. Geol. Soc. Am. Bull. 81, 985-1000.

97) Bergman, B., Gallon, J.R., Rai, A.N. and Stal, L.J. (1997) $\mathrm{N}_{2}$ Fixation by non-heterocystous cyanobacteria. FEMS Microbiol. Rev. 19, 139-185.

98) Capone, D.G., Zehr, J.P., Paerl, H.W., Bergman, B. and Carpenter, E.J. (1997) Trichodesmium, a globally significant marine cyanobacterium. Science 276, 1221-1229.

99) Zehr, J.P., Waterbury, J.B., Turner, P.J., Montoya, J.P., Omoregie, E., Steward, G.F., Hansen, A. and Karl, D.M. (2001) Unicellular cyanobacteria fix $\mathrm{N}_{2}$ in the subtropical North Pacific Ocean. Nature 412, 635-638.

100) Montoya, J.P., Holl, C.M., Zehr, J.P., Hansen, A., Villareal, T.A. and Capone, D.G. (2004) High rates of $\mathrm{N}_{2}$ fixation by unicellular diazotrophs in the oligotrophic Pacific Ocean. Nature 430, 
1027-1031.

101) Pearl, H.W. (1996) A comparison of cyanobacterial bloom dynamics in freshwater, estuarine and marine environments. Phycologia 35, 25-35.

102) Dyhrman, S.T., Chappell, P.D., Haley, S.T., Moffett, J.W., Orchard, E.D., Waterbury, J.B. and Webb, E.A. (2006) Phosphonate utilization by the globally important marine diazotroph Trichodesmium. Nature 439, 68-71.

103) Zerkle, A.L., Junium, C.K., Canfield, D.E. and House, C.H. (2008) Production of ${ }^{15} \mathrm{~N}$-depleted biomass during cyanobacterial $\mathrm{N}_{2}$-fixation at $\mathrm{Fe}$ concentrations. J. Geophys. Res. 113, G03014, doi:10.1029/2007JG000651.

104) Rueter, J.G. (1988) Iron stimulation of photosynthesis and nitrogen fixation in Anabaena 7120 and Trichodesmium (Cyanophyceae). J. Phycol. 24, 249-254.

105) Walsby, A.E. and Reynolds, C.S. (1981) Sinking and floating. In The Physiological Ecology of Phytoplankton (ed. Morris, I.). Blackwell, Oxford, pp. 371-412.

106) Summons, R.E., Jahnke, L.L., Hope, J.M. and Logan, G.A. (1999) 2-Methylhopanoids as biomarkers for cyanobacterial oxygenic photosynthesis. Nature 400, 554-557.

107) Kuypers, M.M.M., van Breugel, Y., Schouten, S., Erba, E. and Sinninghe Damsté, J.S. (2004) $\mathrm{N}_{2}$-fixing cyanobacteria supplied nutrient $\mathrm{N}$ for Cretaeous oceanic anoxic events. Geology 32, 853-856.

108) Dumitrescu, M. and Brassell, S.C. (2005) Biogeochemical assessment of sources of organic matter and paleoproductivity during the early Aptian Oceanic Anoxic Event at Shatsky Rise, ODP Leg 198. Org. Geochem. 36, 1002-1022.

109) Verne-Mismer, J., Ocampo, R., Callot, H.J. and Albrecht, P. (1988) Molecular fossils of chlorophyll-c of the 17-nor-DPEP series. Structural determination, synthesis, geochemical significance. Tetrahedron Lett. 29, 371-374.

110) Kashiyama, Y., Ogawa, N.O., Shiro, M., Tada, R., Kitazato, H. and Ohkouchi, N. (2008) Reconstruction of the biogeochemistry and ecology of photoautotrophs based on the nitrogen and carbon isotopic compositions of vanadyl porphyrins from Miocene siliceous sediments. Biogeosci. 5, $797-816$.

111) Carpenter, E.J. and Romans, K. (1991) Major role of the cyanobacterium Trichodesmium in nutrient cycling in the North Atlantic Ocean. Science 254, $1356-1358$.

112) Rai, A.N., Söderbäck, E. and Bergman, B. (2000) Cyanobacterium-plant symbioses. New Phytol. 147, 449-481.

113) Clark, D.L. (1988) Early history of the Arctic Ocean. Paleoceanography 3, 539-550.

114) Sinninghe Damsté, J.S., Muyzer, G., Abbas, B., Rampen, S.W., Masse, G., Allard, W.G., Belt, S.T., Robert, J.-M., Rowland, S.J., Moldowan, J.M., Barbanti, S.M., Fago, F.J., Denisevich, P., Dahl, J., Trindade, L.A.F. and Schouten, S.
(2004) The rise of the rhizosolenid diatoms. Science 304, 584-587.

115) Kemp, A.E.S., Pearce, R.B., Koizumi, I., Pike, J. and Rance, S.J. (1999) The role of mat-forming diatoms in the formation of Mediterranean sapropels. Nature 398, 57-61.

116) Baroni, I.R., Tsandev, I. and Slomp, C.P. (2014) Enhanced $\mathrm{N}_{2}$-fixation and $\mathrm{NH}_{4}{ }^{+}$recycling during oceanic anoxic event 2 in the proto-North Atlantic. Geochem. Geophys. Geosyst. 15, 40644078.

117) Deutsch, C., Sarmiento, J.L., Sigman, D.M., Gruber, N. and Dunne, J.P. (2007) Spatial coupling of nitrogen inputs and losses in the ocean. Nature 445, 163-167.

118) Coffin, M.F. and Eldholm, O. (1994) Large igneous provinces: Crustal structure, dimensions, and external consequences. Rev. Geophys. 32, 1-36.

119) Eldholm, O. and Coffin, M.F. (2000) Large igneous provinces and plate tectonics. In The History and Dynamics of Global Plate Motions, Geophysical Monograph 121 (eds. Richards, M.A., Gordon, R.G. and van der Hilst, R.D.). American Geophysical Union, Washington, D.C., pp. 309-326.

120) Kerr, A.C., White, R.V. and Saunders, A.D. (2000) LIP reading: recognizing oceanic plateau in the geological record. J. Petrol. 41, 1041-1056.

121) Anderson, D.L. (2005) Large igneous provinces, delamination, and fertile mantle. Elements 1, 271-275.

122) Voigt, P.R. (1972) Evidence for global synchronism in mantle plume convection, and possible significance for geology. Nature 240, 338-342.

123) Larson, R.L. (1991) Geological consequences of superplumes. Geology 19, 963-966.

124) Turgeon, S.C. and Creaser, R.A. (2008) Cretaceous oceanic anoxic event 2 triggered by a massive magmatic episode. Nature 454, 323-326.

125) Du Vivier, A.D.C., Selby, D., Sageman, B.B., Jarvis, I. Gröcke, D.R. and Voigt, S. (2014) Marine ${ }^{187} \mathrm{Os} /{ }^{188}$ Os isotope stratigraphy reveals the interaction of volcanism and ocean circulation during Oceanic Anoxic Event 2. Earth Planet. Sci. Lett. 389, 23-33.

126) Zheng, X.-Y., Jenkyns, H.C., Gale, A.S., Ward, D.J. and Henderson, G.M. (2013) Changing ocean circulation and hydrothermal inputs during Ocean Anoxic Event 2 (Cenomanian-Turonian): Evidence from Nd-isotopes in the European shelf sea. Earth Planet. Sci. Lett. 375, 338-348.

127) Tejada, M.L.G., Suzuki, K., Kuroda, J., Coccioni, R., Mahoney, J.J., Ohkouchi, N., Sakamoto, T. and Tatsumi, Y. (2009) Ontong Java Plateau eruption as a trigger for the early Aptian oceanic anoxic event. Geology 37, 855-858.

128) Kuroda, J., Tanimizu, M., Hori, R.S., Suzuki, K., Ogawa, N.O., Tejada, M.L.G., Coffin, M.F., Coccioni, R., Erba, E. and Ohkouchi, N. (2011) Lead isotopic record of Barremian-Aptian of marine sediments: implications for large igneous provinces and the Aptian climatic crisis. Earth Planet. Sci. Lett. 307, 126-134. 
129) Bottini, C., Cohen, A.S., Erba, E., Jenkyns, H.C. and Coe, A.L. (2012) Osmium-isotope evidence for volcanism, weathering, and ocean mixing during the early Aptian OAE 1a. Geology 40, 583-586.

130) Larson, R.L. and Erba, E. (1999) Onset of the midCretaceous greenhouse in the Barremian-Aptian: Igneous events and the biological, sedimentary and geochemical responses. Paleoceanography 14, 663-678.

131) Neal, C.R., Coffin, M.F., Arnt, N.T., Duncan, R.A., Eldholm, O., Erba, E., Farnetani, C., Fitton, G., Ingle, S.P., Ohkouchi, N., Rampino, M.R., Reicow, M.K., Self, S. and Tatsumi, Y. (2008) Investigation of large igneous province formation and associated paleoenvironmental events: A white paper for scientific drilling. Sci. Drill. 6, $4-18$.

132) Frijia, G. and Parente, M. (2008) Strontium isotope stratigraphy in the upper Cenomanian shallowwater carbonates of the southern Apennines: Short-term perturbations of marine ${ }^{87} \mathrm{Sr} /{ }^{86} \mathrm{Sr}$ during the oceanic anoxic event 2. Palaeogeogr. Palaeoclimatol. Palaeoecol. 261, 15-29.

133) Blättler, C.L., Jenkyns, H.C., Reynard, L.M. and Henderson, G.M. (2011) Significant increases in global weathering during Oceanic Anoxic Events 1a and 2 indicated by calcium isotopes. Earth Planet. Sci. Lett. 309, 77-88.

134) Pogge von Strandmann, P.A.E., Jenkyns, H.C. and Woodfine, R.G. (2013) Lithium isotope evidence for enhanced weathering during Oceanic Anoxic Event 2. Nat. Geosci. 6, 668-672, doi:10.1083/ NGE01875.

135) Misumi, K., Yamanaka, K. and Tajika, E. (2009)
Numerical simulation of atmospheric and oceanic biogeochemical cycles to an episodic $\mathrm{CO}_{2}$ release event: implications for the cause of midCretaceous Ocean Anoxic Event-1a. Earth Planet. Sci. Lett. 286, 316-323.

136) Sinton, C.W. and Duncan, R.A. (1997) Potential links between ocean plateau volcanism and global ocean anoxia at the Cenomanian-Turonian boundary. Econ. Geol. 92, 836-842.

137) Ozaki, K., Tajima, S. and Tajika, E. (2011) Conditions required for oceanic anoxia/euxinia: Constraints from a one-dimensional ocean biogeochemical cycle model. Earth Planet. Sci. Lett. 304, 270-279.

138) Deroo, G., Herbin, J.P., Roucache, J., Tissot, B., Albrecht, P. and Schaeffle, J. (1978) Organic geochemistry of some Cretaceous black shales from sites 367 and 368; Leg 41, Eastern North Atlantic. Init Rep DSDP 41, 865-874.

139) Joyce, R.M. and Van Vleet, E.S. (1986) Origin of organic matter in North Atlantic Basin Cretaceous black shales. In Organic Marine Geochemistry (ed. Sohn, M.L.). American Chemical Society, Washington, D.C., pp. 91-106.

140) Kashiyama, Y., Ogawa, N.O., Kitazato, H. and Ohkouchi, N. (2010) Nitrogen and carbon isotopic compositions of copper, nickel, and vanadyl porphyrins in Cretaceous OAE black shales. In Earth, Life, and Isotopes (eds. Ohkouchi, N., Tayasu, I. and Koba, K.). Kyoto University Press, Kyoto, pp. 313-335.

(Received Feb. 4, 2015; accepted May 13, 2015)

\section{Profile}

Naohiko Ohkouchi was born in Kyoto in 1966. He graduated from the University of Tokyo in 1990, and received Ph.D. from Department of Geology, the University of Tokyo in 1995 under the supervision of Prof. Asahiko Taira. He applied organic geochemical methods to the oceanic sediments for reconstructing the paleoclimate during the late Quaternary. He spent a year as a JSPS postdoctoral fellow at Center for Ecological Research, Kyoto University working under Prof. Eitaro Wada, and then became an assistant professor at Institute of Low Temperature Science, Hokkaido University. In 1999 he moved to Woods Hole Oceanographic Institution where he started to work compound-specific radiocarbon dating in collaboration with Dr. Timothy I. Eglinton and Dr. John M. Hayes. In 2002, he joined a member of JAMSTEC. He is also applying

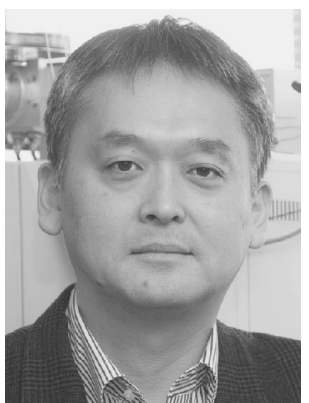
nitrogen isotopic composition of amino acids to understand feeding ecology of various ecosystems. Dr. Ohkouchi is currently the director of Department of Biogeochemistry, JAMSTEC and a visiting professor of Department of Environmental Chemistry and Engineering, Tokyo Institute of Technology. 


\section{Profile}

Junichiro Kuroda was born in Osaka in 1977. He graduated from Tsukuba University in 2000. He received Ph.D. degree in 2005 in the University of Tokyo, whose thesis is entitled "Anatomy of Cretaceous black shales". His multidisciplinary geological and geochemical studies principally focusing on the Cretaceous oceanic anoxic events (OAEs) have contributed greatly to our understanding of this extreme warm phase in Earth History. In particular, his researches about heavy metal isotopes (osmium and lead) of Mesozoic sediments demonstrated that some extreme climatic events of Earth's surface were closely linked to the deep Earth processes such as emplacement of large igneous provinces associated with mantle plume upwelling. His scientific playground is onland outcrops and deep subseafloor. He has been involved in the International Ocean

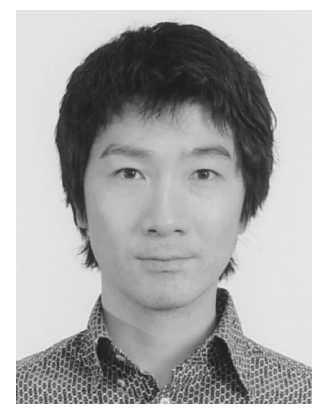
Discovery Program (IODP), and has sailed over the world's oceans with drilling vessels Chikyu and JOIDES Resolution. He stayed in the National Oceanography Centre, University of Southampton, UK (2010-2011) as a visiting scientist, and studied Cenozoic paleoceanography. For his significant contributions to this field, he received the Yoshiaki Ozawa Prize (award for young scientists) of the Geological Society of Japan in 2011, and the Geochemical Society of Japan Award for Young Researchers in 2011. Recently, he is involved in an international project of Mediterranean Sea drilling, where thick evaporite succession of the latest Miocene (Messinian) underlies deep basins.

\section{Profile}

Asahiko Taira was born in Sendai in 1946. He graduated Department of Geology, Tohoku University. He received Ph.D. from University of Texas at Dallas in 1976. In 1977 he was appointed as an associate professor at Kochi University where he taught geology and led the research on the Shimanto accretionary complex. From 1985, he moved to Ocean Research Institute of the University of Tokyo where he was a leader in the research of marine geology in the Nankai Trough and scientific ocean drilling. He has taken an initiative on epoch-making researches for understanding evolution of Japan Arc through field geological and submarine geophysical analyses. His study further extended to the evolution of continental crust, orogenesis, as well as paleoceanography. In 2002, he moved to JAMSTEC to take a leadership in the operation of D/V Chikyu and related

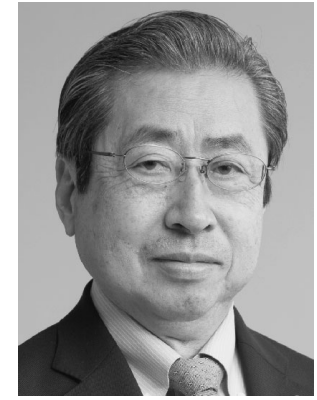
projects. He is now president of JAMSTEC. He also served as President of the Geological Society of Japan from 2002 to 2004. He received the Japan Academy Prize in 2007. In 2014, "The Asahiko Taira International Scientific Ocean Drilling Research Prize", which is given in honor of him, was established under a partnership between the American Geophysical Union (AGU) and the Japan Geoscience Union (JpGU). 